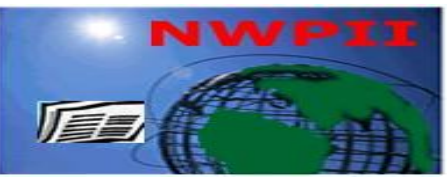

American Journal of Biomedical Sciences

ISSN: 1937-9080

nwpii.com/ajbms

\title{
Comparative Study for the Therapeutic Effect of Shark Care and 5- Fluorouracil Drugs in Mice with Hepatocelluar Carcinoma in the Presence of Electric Field
}

\author{
Rasha Said shams El Dine ${ }^{1}$, Samir Ali Abd El-kaream ${ }^{2}$, Soheir Mahmoud Elkholy ${ }^{1}$, \\ Nadia Ahamed Abd El maniem ${ }^{3}$
}

\author{
${ }^{1}$ Medical Biophysics Department, Medical Research Institute, Alexandria University, Alexandria, Egypt \\ ${ }^{2}$ Applied Medical Chemistry Department, Medical Research Institute, Alexandria University, Alexandria, Egypt \\ ${ }^{3}$ Cancer Management and Research Department, Medical Research Institute, Alexandria University, Alexandria, \\ Egypt \\ "Corresponding Author \\ Rasha Said Shams El-Dine \\ Medical Biophysics Department \\ Medical research Institute \\ Alexandria University \\ Alexandria 2(03), Egypt \\ E-mail: Rasha_shams17@yahoo.com
}

Received: 11 April 2015; | Revised: 30 April 2015; | Accepted: 1 June 2015

\begin{abstract}
Hepatocelluar carcinoma (HCC) is the third deadliest and fifth most common cancer worldwide. Many drugs that have the potential to treat cancers have had limited success due to their lack of efficient and safe delivery mechanisms that allow the drug molecules to cross cell membranes. Electrical pulses-mediated drug delivery, known as electroporation, is gaining attention as a possible approach to enhance uptake of chemotherapy. It delivers anticancer drugs with enhanced efficacy and fewer adverse effects. It is a physical (Thus, applicable to all types of tumors) and is minimally invasive. The aim of the present work was to compare the therapeutic effect of shark care and 5-Fluorouracil drugs in mice with HCC in the presence of electric field. The present study was conducted on 50 albino mice weighting 20-25 gm of 8-10 weeks of age were divided into gp (A) (control), gp (B-1), (That donot recive any treatment), gp (B-2) (which treated by injected by $120 \mathrm{mg} / \mathrm{kg}$ of 5-Fluorouracil), gp (B-3) (which treated by shark care drug dissolved in drinking water daily). And after this treatment period part of gp (B-2-i), gp (B-3-i) don't exposed to electric field while gp (B-2 -ii) and gp (B-3-ii) were exposed to electric field for 5 second and the last part gp (B-2-iii) and gp (B-3-iii) were exposed to electric field for 10 second. Parts of liver tissue and blood samples were collected from all from mice of each group for histopathological examination, biophysical study (Capacitance and resistance were measured using LCR meter over a freguency range from 1-100KHz and the measured values were used to calculate permittivity and conductivity) and biochemical study (molecular detection of Alpha-fetoprotein (AFP) and transforming growth factor beta-1(TG $\beta 1$ ) mRNAs by RT-PCR) before and after treatment by shark care and 5-Fluorouracil drugs in mice with HCC in the presence of
\end{abstract}


electric field. During the whole course of experiment the histopathological changes were synchronized with the biophysical (permittivity and conductivity) and biochemical (AFP and TG $\beta 1$ mRNAs gene expression) changes. shark care drug showed promising effective results for treatment of HCC compared to results obtained with 5-Fluorouracil drug. presence of electric field results in reduced tumor growth, and induction of apoptosis in the treated cells by enhanceing uptake of chemotherapy and delivering anticancer drugs with enhanced efficacy and fewer adverse effects.

Keywords: 5-Fluorouracil, shark care AFP-mRNA, TG $\beta 1$ mRNA, DAB, HCC.

\section{Introduction}

Liver cancer rapidly reduces quality of life and typically causes death 6 months : 1 year from diagnosis. ${ }^{(1)}$ Globally, it is the fifth in cancer incidence and the third leading cause of cancer death. ${ }^{(1,2)}$ In Egypt, between 1993 and 2003, there was an almost two fold increases from about $4 \%$ in 1993 to $7.3 \%$ in 2003) in HCC among patients with chronic liver diseases. (3-6) Egypt is now plagued by the highest prevalence of HCC in the world, which ranged from 6 to $28 \%$ and a reported average of about $13.8 \%$. ${ }^{(7,8)}$ Recent investigations in Egypt have also shown the increasing importance of $\mathrm{HCV}$ infection in the aetiology of $\mathrm{HCC}$, which now estimated to account for $40-50 \%$ of cases. ${ }^{(4-6)}$

The best characterized agents of chemotherapeutic drugs for the treatment of HCC are the halogenated pyramidnes, a group that includes fluorouracil (5-fluorouracil or 5-Fu). Or floxwridine (5-fluoro 2 deoxyuridine, or 5- FudR) and idoxuridine (5-iododeoxy uridine). ${ }^{(9)}$

The treatment by new specific antiangiogenic drug and monitoring such treatment need reliable standardized and useful predicative markers of antiangiogenesis. (10) Such biomarker must be easily measurable, reflecting accurately the pathological process that it is designed to measure and must provide the clinician with an answer that can be easily interpreted. ${ }^{(11)}$

Shark care drug is a purified Shark cartilage extract composed of the following ingredients: proteins: (Collagen, U-995 protein and SCF2 protein), glycosaminoglycans: (Chondroitin-6sulfate and keratin sulphate) and calcium salts. (12)

Many drugs that have the potential to treat cancers have had limited success due to their lack of efficient and safe delivery mechanisms that allow the drug molecules to cross cell membranes. Electrical pulses-mediated drug delivery, known as electroporation, is gaining attention as a possible approach to enhance uptake of chemotherapy. It delivers anticancer drugs with enhanced efficacy and fewer adverse effects. It is a physical (Thus, applicable to all types of tumors) and is minimally invasive.

The aim of the present work was to compare the therapeutic effect of shark care and 5Fluorouracil drugs in mice with HCC in the presence of electric field.

The study was done on fifty albino mice weighting 20-25 gm of 8-10 weeks of age were divided into four groups.

Group A: 10 mice were used as a control group, group B: 40 mice have induced HCC by $\mathrm{DABE}$ this group were subdivided into three sub-groups; sub group B - 1: 10 mice which were not received any treatment, and were kept at room environment and were exposed to (LG1100) MCP corp, sub group B - 2: 15 mice were injected intraperitoneal with $120 \mathrm{mg} / \mathrm{kg}$ body weight of 5-Fluorouracil dose every day for 21days and divided into( sub group B - $2 \mathrm{i}$ : 5 mice were sacrificed for histopathological after 21 days, sub group B 2ii: 5 mice were exposed to (LG1100) MCP corp for $5 \mathrm{sec}$ after 21 days, sub group B 2iii:5 mice were exposed to (LG1100) MCP corp for $10 \mathrm{sec}$ after 21 days) and sub group B - 3: 15 mice were treated by shark care drug dissolved in drinking water daily for 21 days and divided into (sub group $\mathrm{B}-3 \mathrm{i}: 5$ mice were sacrificed and histopathological after 21 days, sub group B - 3 ii:5 mice were exposed to (LG1100) MCP corp for $5 \mathrm{sec}$ after 21 days, sub group B -3 iii:5 mice were 
exposed to (LG1100) MCP corp for $10 \mathrm{sec}$ after 21 days)

\section{Histopathological Examination}

Parts of liver tissue from mice of each previous groups were processed and examined by Hematoxylin and Eosin (H\&E). ${ }^{(13)}$

\section{Biophysical Examination}

\subsection{Measuring electrodes}

Each sample was connected to the LCR meter (Instek Model 819, Japan ) by means of two silver-silver chloride electrodes. Specimens were inserted in contact between the two electrodes. The electrodes were held in position during the measurements by means of gallows like stand, the gallows used only for convenience in supporting the movable electrode. Sliver chloride electrodes provided a good contact within minimum polarization and compatibility with biological cells. The contact to the specimen was through KCL gel.

\subsection{Measurements}

Capacitance $\mathrm{C}$ and resistance $\mathrm{R}$ was measured using LCR meter (Good will instrument Co. Ltd, Hsien Taiwan) over a freguency range from $1-100 \mathrm{KHz}$. The measured values were used to calculate permittivity and conductivity.

The relative dielectric permittivity and conductivity were calculated from the equation: ${ }^{(14)}$

$$
\begin{aligned}
& \mathrm{C}=\mathcal{E}^{\prime} \varepsilon_{\mathrm{o}} \mathrm{A} / \mathrm{d} \\
& \mathrm{G}=\sigma \mathrm{A} / \mathrm{d}
\end{aligned}
$$

Where $\mathrm{C}$ and $\mathrm{G}$ were the capacitance and conductance of the capacitor between the two measuring electrodes in (Farad) and in (Siemens), respectively, A was the surface area of the electrode in $\left(\mathrm{m}^{2}\right), \mathrm{d}$ was the separation between the two electrodes in $(\mathrm{m}), \mathcal{E}^{\prime}$ was the relative permittivity in (farad/meter), $\varepsilon_{\mathrm{o}}$ was the permittivity of vacum $\left(8.85 \times 10^{-12} \mathrm{~F} / \mathrm{m}\right)$ and $\sigma$ was the electrical conductivity in (Siemens/ $\mathrm{m}$ )
The imaginary parts of complex permeittivity $\varepsilon^{\prime \prime}$ and conductivity $\sigma^{\prime \prime}$ were calculated according to the relation. ${ }^{(15,16)}$

$$
\begin{aligned}
& \mathcal{E}^{\prime \prime}=\left(\sigma-\sigma_{\mathrm{L}}\right) / 2 \pi \mathrm{f}_{2} \varepsilon_{\mathrm{o}} \\
& \sigma^{\prime \prime}=2 \pi \mathrm{f}_{2} \varepsilon_{\mathrm{o}}\left(\mathcal{E}-\varepsilon_{\mathrm{h}}\right)
\end{aligned}
$$

Where: $\sigma_{\mathrm{L}}$ was the low frequency limiting conductivity taken at $1 \mathrm{KHz} \varepsilon_{\mathrm{h}}$ was the high frequency limiting permittivity taken at 100 KHZ.

\section{Biochemical Examination}

\subsection{RT-PCR for AFP- $m R N A$ and TGß1- mRNA genes expression amplification}

\subsubsection{RNA extraction:}

RNA was extracted from the serum of mice using QIAamp RNA blood mini kit, was purchased from QIAGEN, USA according to the manufacturer's instructions.

Preparation of Full-Length First strand cDNA from RNA template using RevertAid ${ }^{\mathrm{TM}}$ First Strand cDNA Synthesis Kit. ${ }^{(17)}$

\subsubsection{Reverse transcription}

Reverse transcription reaction was carried out in a $20 \mu \mathrm{l}$ reaction mixture by using RevertAid ${ }^{\mathrm{TM}}$ First Strand cDNA Synthesis Kit Cdna Synthesis Kit\# K1621,\#1622, was purchased from MBI Fermentas, Lithuania according to manufacture's instruction.

\subsubsection{RT-PCR amplification}

To each PCR tube the following were added $5 \mu \mathrm{l}(0.25 \mu \mathrm{g})$ Template AFP-cDNA, $10 \mu 12 \mathrm{Taq}$ TM Green PCR Master Mix (2X) \{dNTPs [0.4 $\mathrm{mM}$ of each dATP, dCTP, dGTP, dTTP], $0.05 \mathrm{u} / \mu \mathrm{l}$ Taq DNA polymerase and reaction buffer\} \# k1081, was purchased from MBI Fermentas, Lithuania, 1.5 $\mu \mathrm{l}$ AFP forward primer: 5' - TGAGCTTCCTGCATTGGGAG - 3, $1.5 \mu 1 \quad$ AFP reverse primers: $5^{\circ}$ CCCGCCAGCATCATAGCTTA - $3{ }^{\prime}$ and deionized-RNase free water to final volume 20 $\mu 1$. The reaction mixtures were gently vortexed, briefly centrifuged to collection all drops to the bottom of the tubes, then were placed in the 
thermal cycler (Little Genius, Bioer Co), The PCR mixture was subjected to 35 amplification cycles. PCR conditions were as follows: An initial denaturation $\left(94^{\circ} \mathrm{C}, 2 \mathrm{~min}\right)$, followed by 35 cycles of denaturation $\left(94^{\circ} \mathrm{C}, 1 \mathrm{~min}\right)$, annealing $\left(52^{\circ} \mathrm{C}, 1 \mathrm{~min}\right)$, and extension $\left(72^{\circ} \mathrm{C}, 1 \mathrm{~min}\right)$, with a final extension $\left(72^{\circ} \mathrm{C}, 7 \mathrm{~min}\right)$.

To each PCR tube the following were added $5 \mu \mathrm{l}(0.25 \mu \mathrm{g})$ Template TG $\beta 1$ - cDNA, $10 \mu 12 \mathrm{X}$ PCR Master Mix $\{\mathrm{dNTPs}[0.4 \mathrm{mM}$ of each dATP, dCTP, dGTP, dTTP], $0.05 \mathrm{u} / \mu \mathrm{l}$ Taq DNA polymerase and reaction buffer\}, $1.5 \mu \mathrm{l}$ AFP forward primer: 5 GTCCTGGCCTTAGCTGTCTT- 3, $1.5 \mu \mathrm{l}$ AFP reverse primers: 5 , ATTCCATAGGCCTGTGACGC- 3 ' and deionized-RNase free water to final volume 20 $\mu 1$. The reaction mixtures were gently vortexed, briefly centrifuged to collection all drops to the bottom of the tubes, then were placed in the thermal cycler (Little Genius, Bioer Co), The PCR mixture was subjected to 35 amplification cycles. PCR conditions were as follows: An initial denaturation $\left(94^{\circ} \mathrm{C}, 2 \mathrm{~min}\right)$, followed by 35 cycles of denaturation $\left(94^{\circ} \mathrm{C}, 1 \mathrm{~min}\right)$, annealing $\left(52^{\circ} \mathrm{C}, 1 \mathrm{~min}\right)$, and extension $\left(72^{\circ} \mathrm{C}, 1 \mathrm{~min}\right)$, with a final extension $\left(72^{\circ} \mathrm{C}, 7 \mathrm{~min}\right)$.

To verify the successful preparation of mRNA and as positive controls, samples were detected for the presence of glyceraldehyde-3phosphate dehydrogenase (GAPDH) mRNA. forward primer: 5 AGGCCGGTGCTGAGTATGTC - 3, reverse primers: 5' - TGCCTGCTTCACCACCTTCT - 3. Reaction tubes containing no cDNA control template and without cDNA sample addition were included as negative controls for each PCR reaction.

\subsection{Detection}

The amplicons were analyzed with $2 \%$ (wt/vol) ethidium bromide stained agarose gel.
The bands were visualized on a $302 \mathrm{~nm}$ UV transilluminator (BIO-RAD, USA).The gel was examined for bands of 294bp as determined by the molecular weight marker (Gene Ruler TM 100bp plus DNA Ladder, ready-to-use\#SM0323, was purchased from Fermentas, Lithuania) runs at the same time and then photographed using digital camera (SONY Super Steady Shot DSCW300).

\section{Results}

In the present work Histological examination was performed on all study groups and Coded $\mathrm{H}$ and E stained slides were examined microscopically by a single pathologist using a high power (magnification, $\times 400$ ), and at least five high-power fields were examined to detect histopathological changes: gp (A) (control); showed 1- normal hepatic architectiure, gp (B-1), (That donot recive any treatment); showed less preserved hepatic architecture with focal cytoplasmic vaculation of hepatocyte, mild fibrosis and lymphatic infiltration 2- vascular degeneration and ballooning of hepatocyte with moderate fibrosis 3- areas of coagulative necrosis 4- various degree of dysplasia and finally HCC, gp (B-2) (which treated by injected by $120 \mathrm{mg} / \mathrm{kg}$ of 5-Fluorouracil); showed moderate lymphatic infiltration also moderate necrosis and moderate nuclear displeases (nuclear elnargment prominent nuclei), gp (B-3) (which treated by shark care drug dissolved in drinking water daily); showed showed miled lymphatic infiltration also mild necrosis and mild nuclear displeases (nuclear elnargment prominent nuclei), gp (B-2-ii) and gp (B-3-ii) were exposed to electric field for 5 second and the last part gp (B-2-iii) and gp (B-3iii) were exposed to electric field for 10 second; showed no fibrosis and no necrosis with relative chromatin distribution and relativelynormal hepatocyte. 


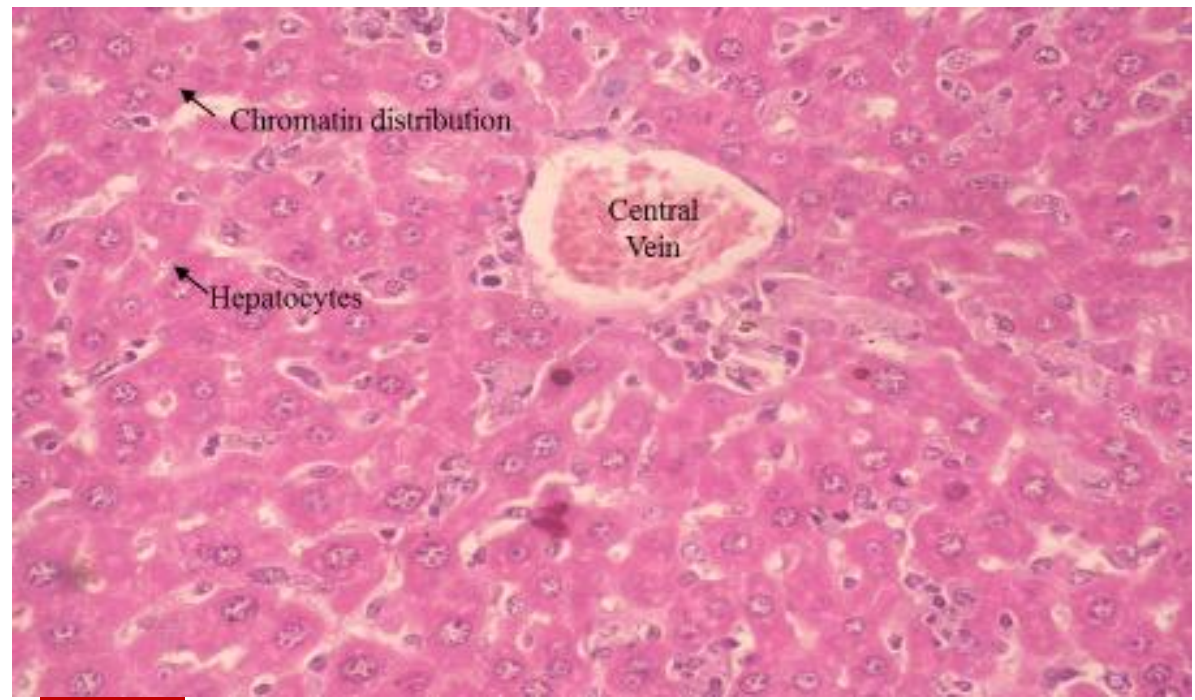

Figure(1): The group of control normal hepatocytes showing no dysplasia.

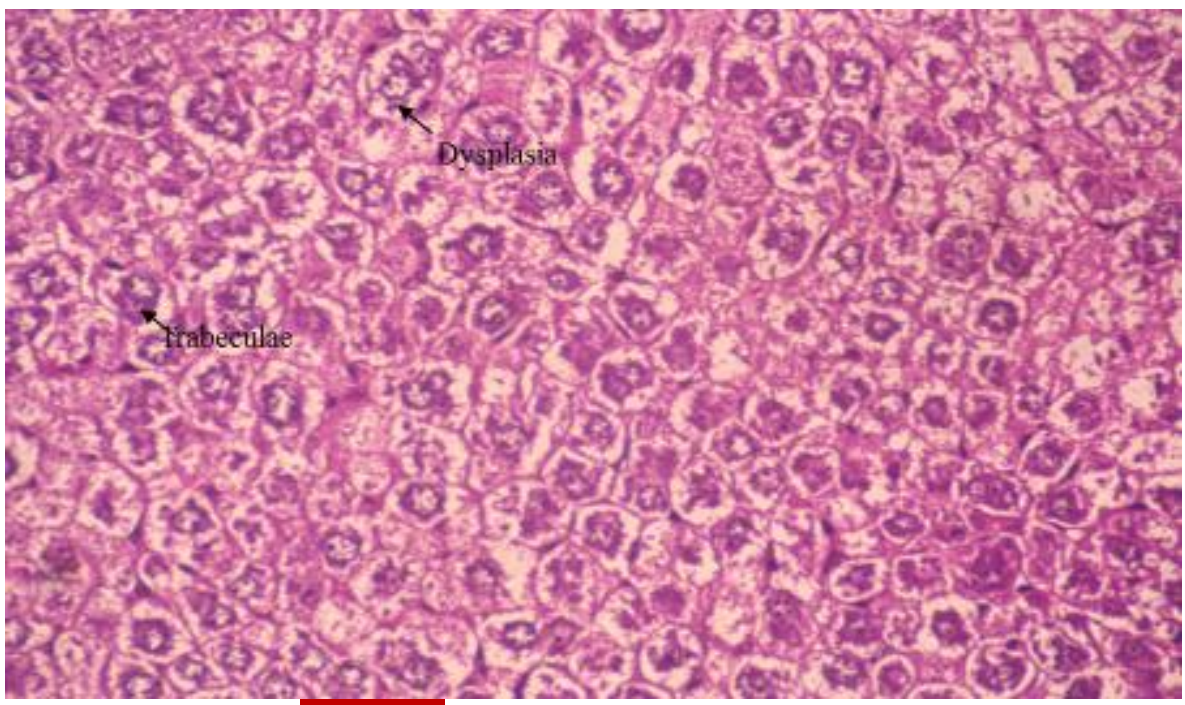

Figure(2): The groups that have HCC.

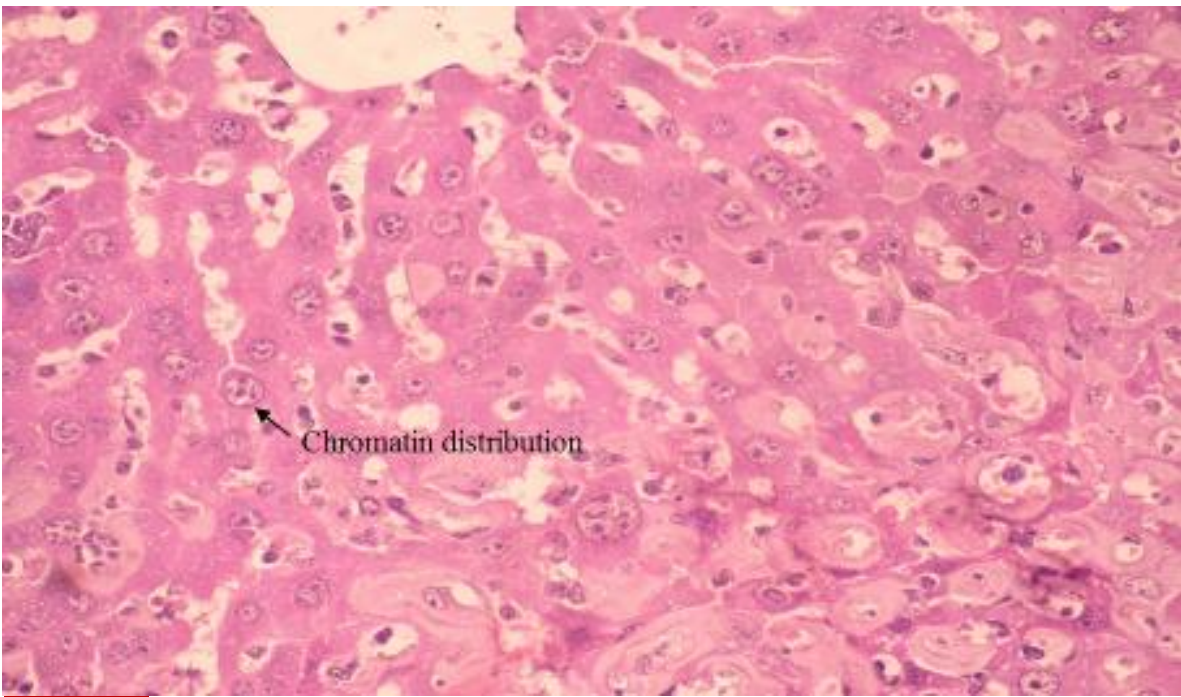

Figure(3): The group of 5- Fluorouracil after 21 days and exposed to electric field for $5 \mathrm{sec}$ reveals change in pattern of chromatin distribution . 


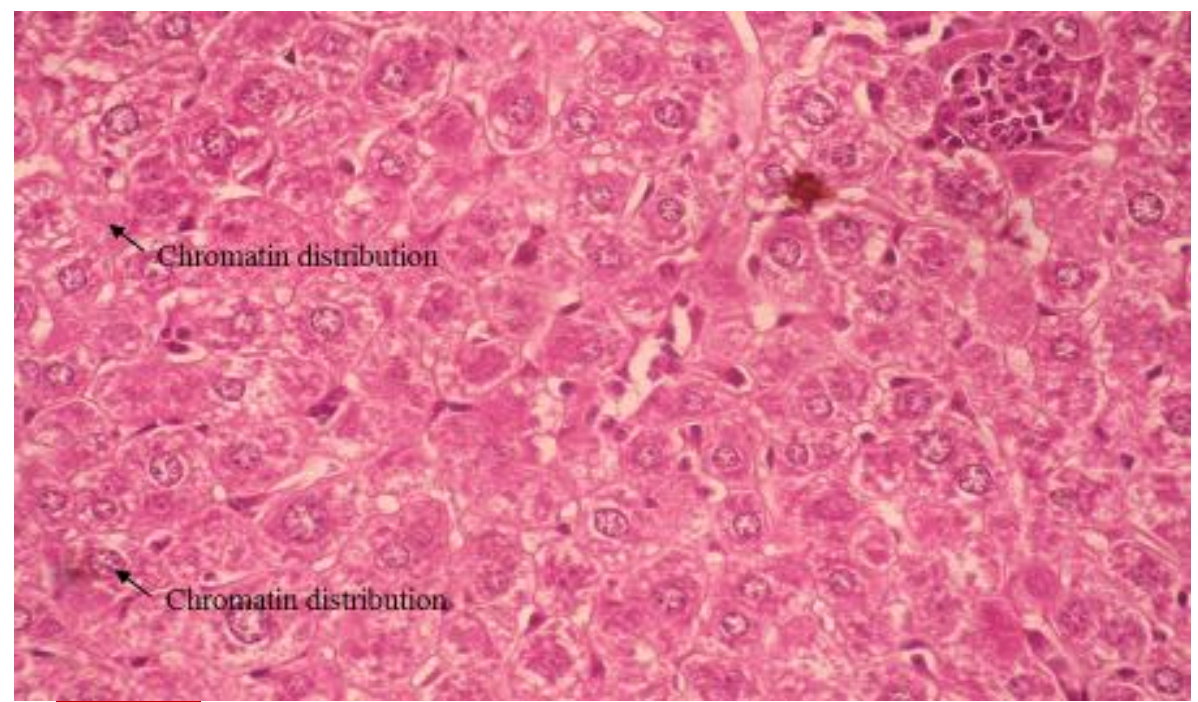

Figure(4): The group of 5- Fluorouracil after 21 days exposed to electric field for $10 \mathrm{sec}$ reveals change in pattern of chromatin distribution

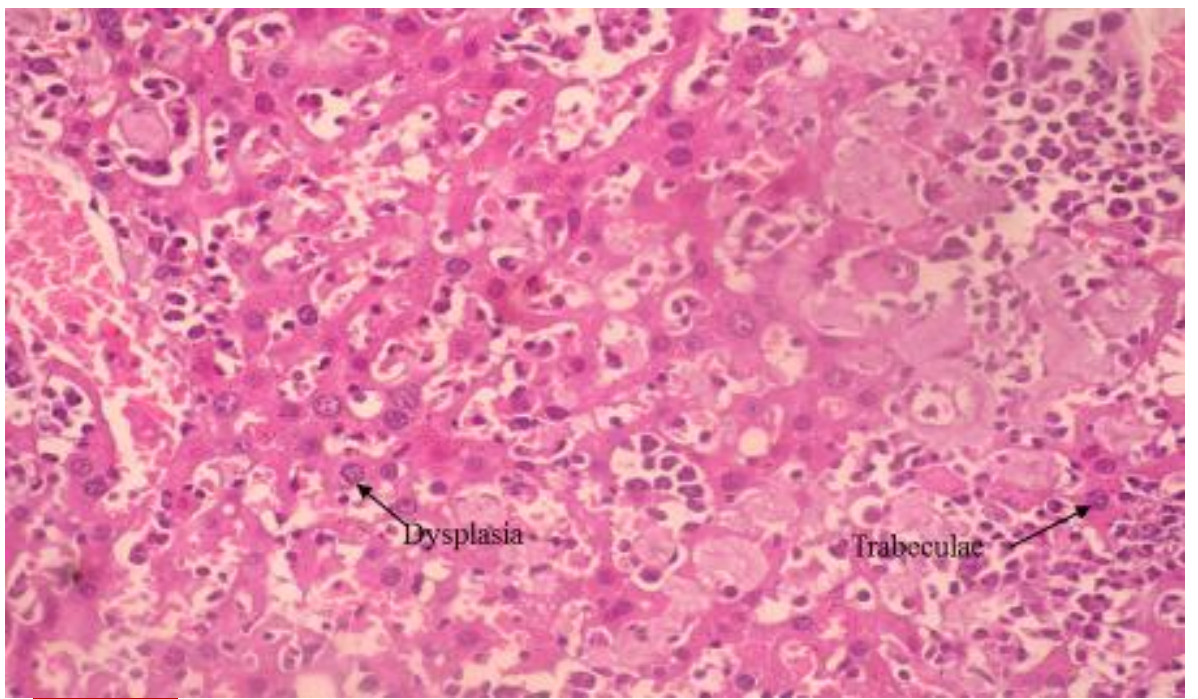

Figure(5): The group of Shark care after 21 days exposed to electric field for $5 \mathrm{sec}$ reveals in pattern of chromatin distribution.

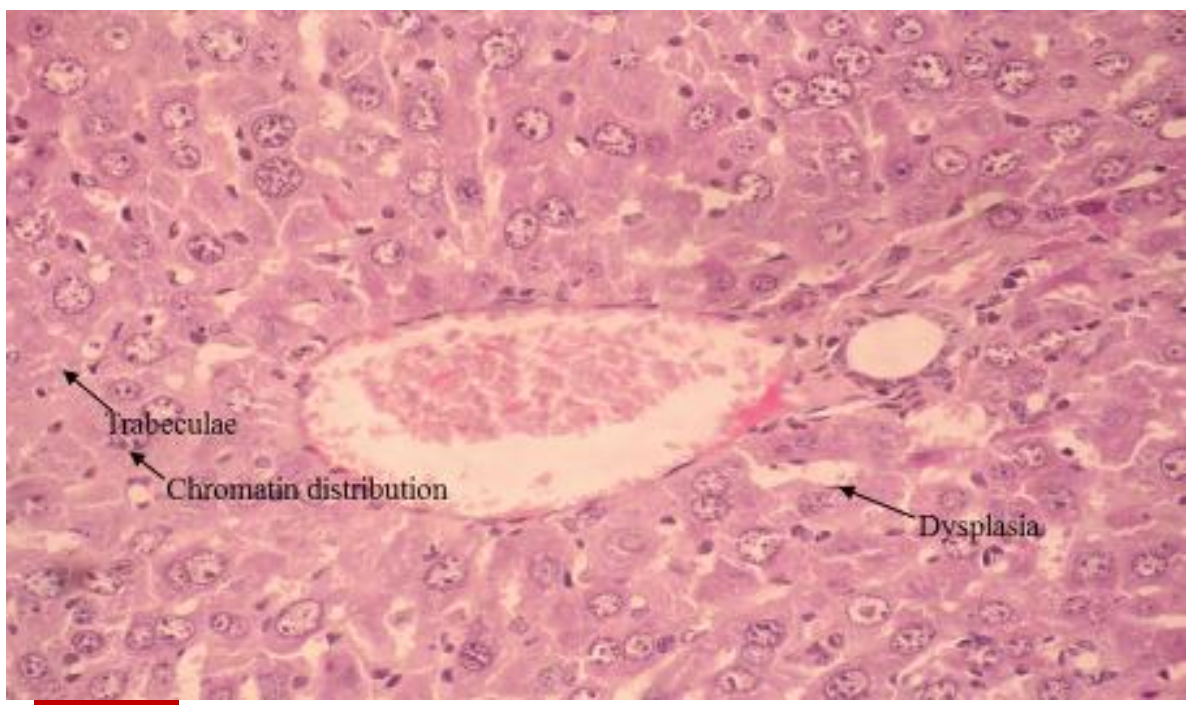

Figure(6): The group of Shark care after 21 days exposed to electric field for $10 \mathrm{sec}$ reveals change in pattern of chromatin distribution. 
i - Dielectric parameters of mice's liver tissue.

a- Effects of different doses of 5- fluorouracil a shark care on permittivity and conductivity variation with frequency.

Figures (7-16) show set of the measured permittivity, and conductivity with the frequency of mice liver tissues of gp (A) (control), gp (B-2) (which treated by injected by $120 \mathrm{mg} / \mathrm{kg}$ of 5-Fluorouracil) and gp (B-3) (which treated by shark care drug dissolved in drinking water daily). Generally, the permiitivity decrease, while the real conductivity increases with increasing of frequeny.

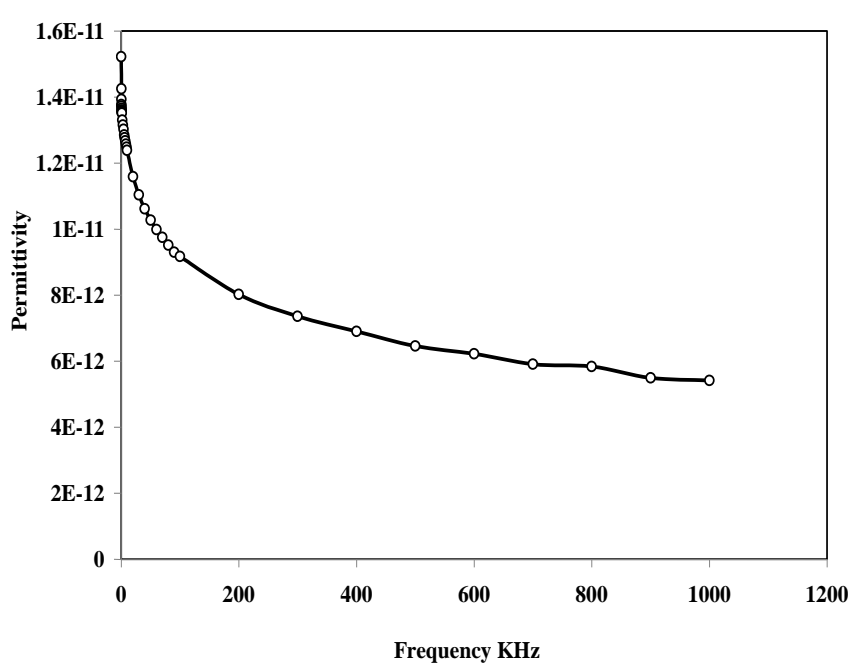

Figure (7): Variation of permittivity with frequency for mice liver tissues Control.

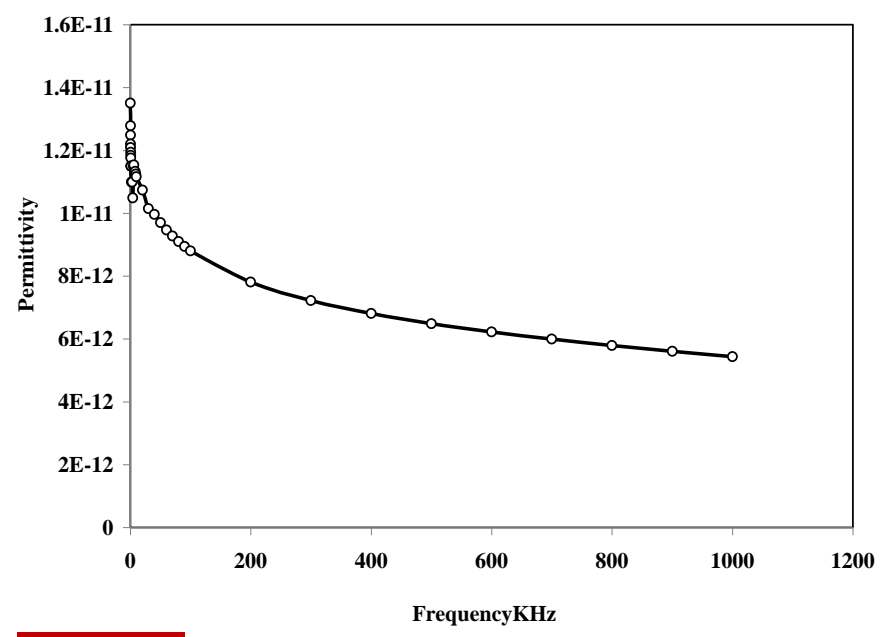

Figure (9): Variation of permittivity with frequency of mice liver tissues treated by injected by 120 $\mathrm{mg} / \mathrm{kg}$ of 5-Fluorouracil after exposed to electric field for $5 \mathrm{sec}$.

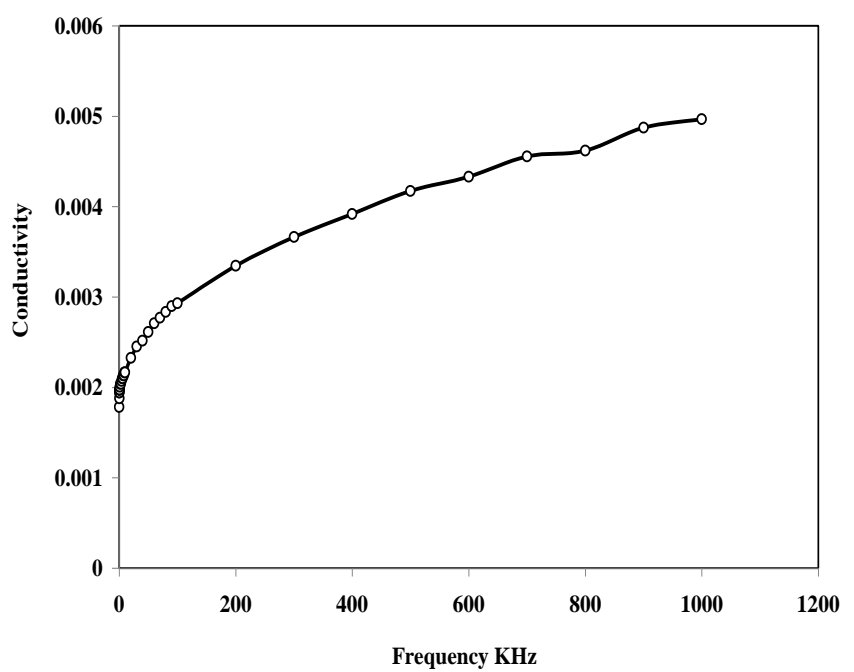

Figure (8): Variation of Conductivity with frequency for mice liver tissues Control.

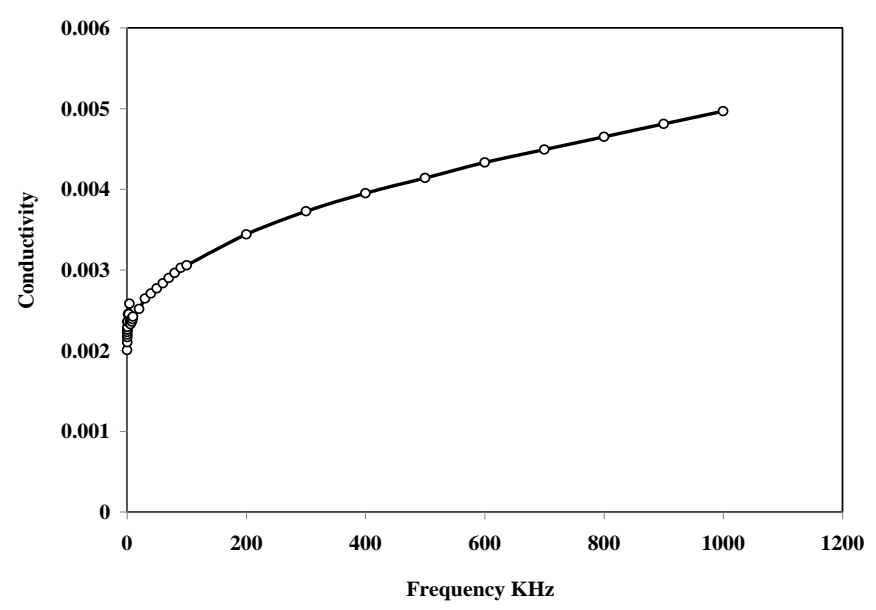

Figure (10): Variation of conductivity with frequency of mice liver tissues treated by injected by 120 $\mathrm{mg} / \mathrm{kg}$ of 5-Fluorouracil after exposed to electric field for $5 \mathrm{sec}$. 


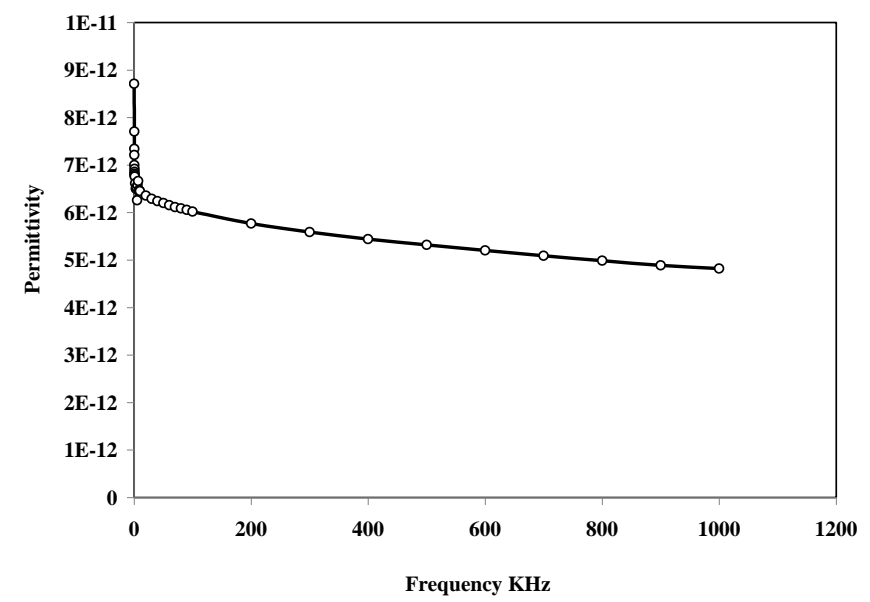

Figure (11): Variation of permittivity with frequency of mice liver tissues treated by injected by $120 \mathrm{mg} / \mathrm{kg}$ of 5 Fluorouracil after exposed to electric field for $10 \mathrm{sec}$.

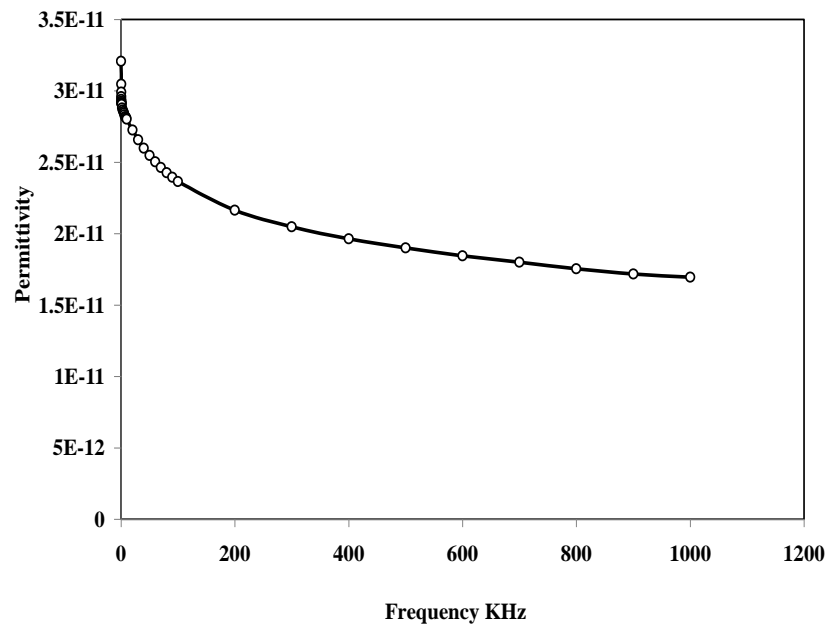

Figure (13): Variation of permittivity with frequency of mice liver tissues treated by shark care drug dissolved in drinking water daily after exposed to electric field for $5 \mathrm{sec}$.

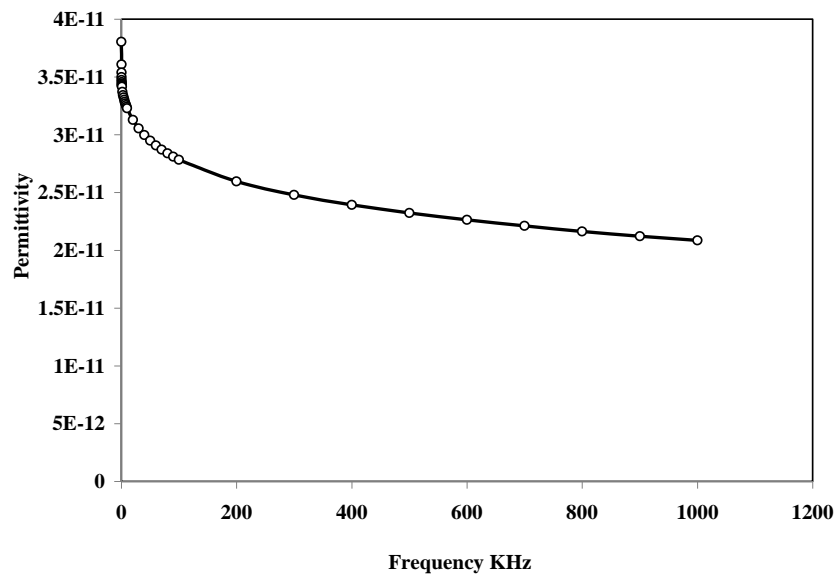

Figure (15): Variation of permittivity with frequency of mice liver tissues treated by shark care drug dissolved in drinking water daily after exposed to electric field for 10 sec.

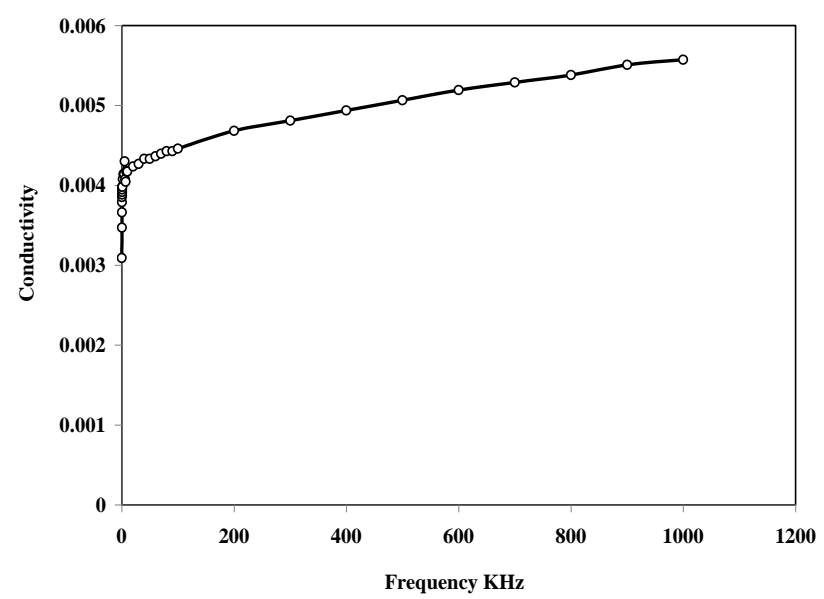

Figure (12): Variation of conductivity with frequency of mice liver tissues treated by injected by $120 \mathrm{mg} / \mathrm{kg}$ of 5 Fluorouracil after exposed to electric field for $10 \mathrm{sec}$.

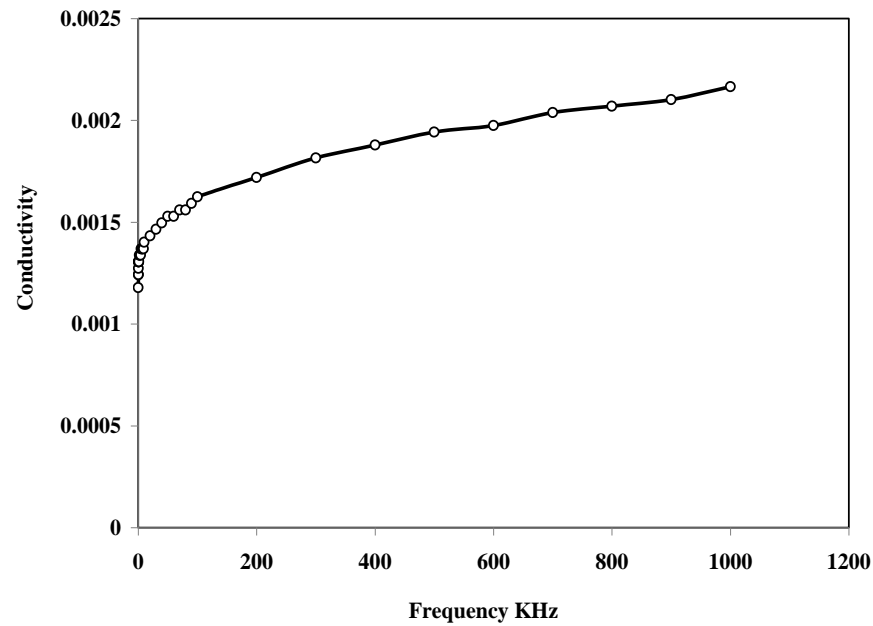

Figure (14): Variation of conductivity with frequency of mice liver tissues treated by shark care drug dissolved in drinking water daily after exposed to electric field for 5 sec.

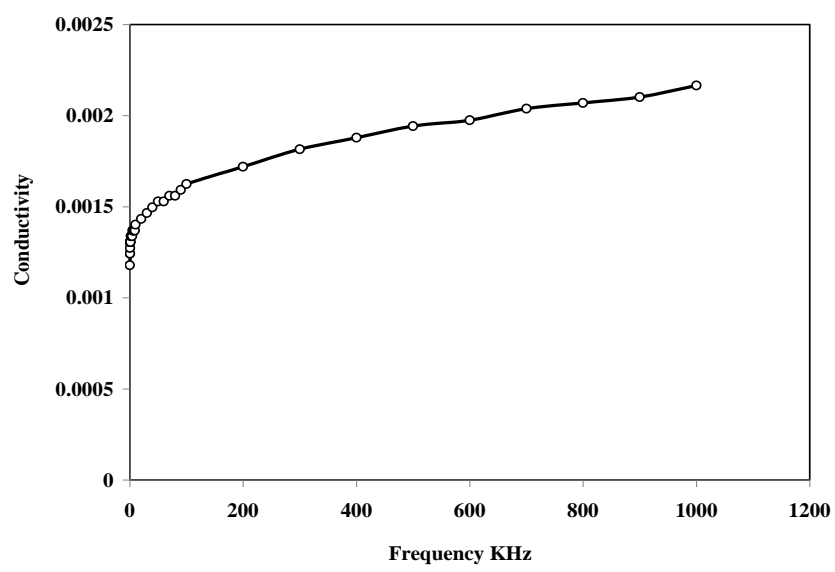

Figure (16): Variation of conductivity with frequency of mice liver tissues treated by shark care drug dissolved in drinking water daily after exposed to electric field for 10 sec. 
Figures (17-18), Illustrate the diagrams of complex permittivity and conductivity of liver tissues of gp (A) (control), gp (B-1), (That donot recive any treatment), gp (B-2) (which treated by injected by $120 \mathrm{mg} / \mathrm{kg}$ of 5-Fluorouracil), gp (B-3) (which treated by shark care drug dissolved in drinking water daily). And after this treatment period part of gp (B-2-i), gp (B-3-i) Which exposed to electric field for 5 second while gp (B-2 -ii) and gp (B-3-ii) were exposed to electric field for 10 second. As seen in these diagrams the depree of deppressed center and the maximum values of the real and imaginary permittivity and conductivity depend on the dose of paraqat used.

The Complex permittivity diagram Figure (17), follow the Cole-Cole semi circule pattern except at low frequency due to cell polarization. The maximum permittivity peaks corresponding to groups treated by injected by $120 \mathrm{mg} / \mathrm{kg}$ of 5 Fluorouracil after exposed to electric field for $5 \mathrm{sec}$, groups that treated by same dose of 5-Fluorouracil but exposed to electric field for $10 \mathrm{sec}$, groups tissues treated by shark care drug dissolved in drinking water daily after exposed to electric field for $5 \mathrm{sec}$, and groups treated by shark care drug dissolved in drinking water daily after exposed to electric field for $10 \mathrm{sec}$ are lower and have a small reative distance of base decrement than that of control group. i.e., The semi circle radii of gp (B-2i) (group that treated by injected by $120 \mathrm{mg} / \mathrm{kg}$ of 5 Fluorouracil after exposed to electric field for 5 sec), gp (B-3-i) (group that treated by shark care drug dissolved in drinking water daily after exposed to electric field for $5 \mathrm{sec}$ ), gp (B-2 -ii) (group that treated by injected by $120 \mathrm{mg} / \mathrm{kg}$ of 5 -Fluorouracil after exposed to electric field for $10 \mathrm{sec}$ ) and gp (B-3-ii) (group that treated by shark care drug dissolved in drinking water daily after exposed to electric field for $10 \mathrm{sec}$ ).are smaller than that of the gp (A) (control) .

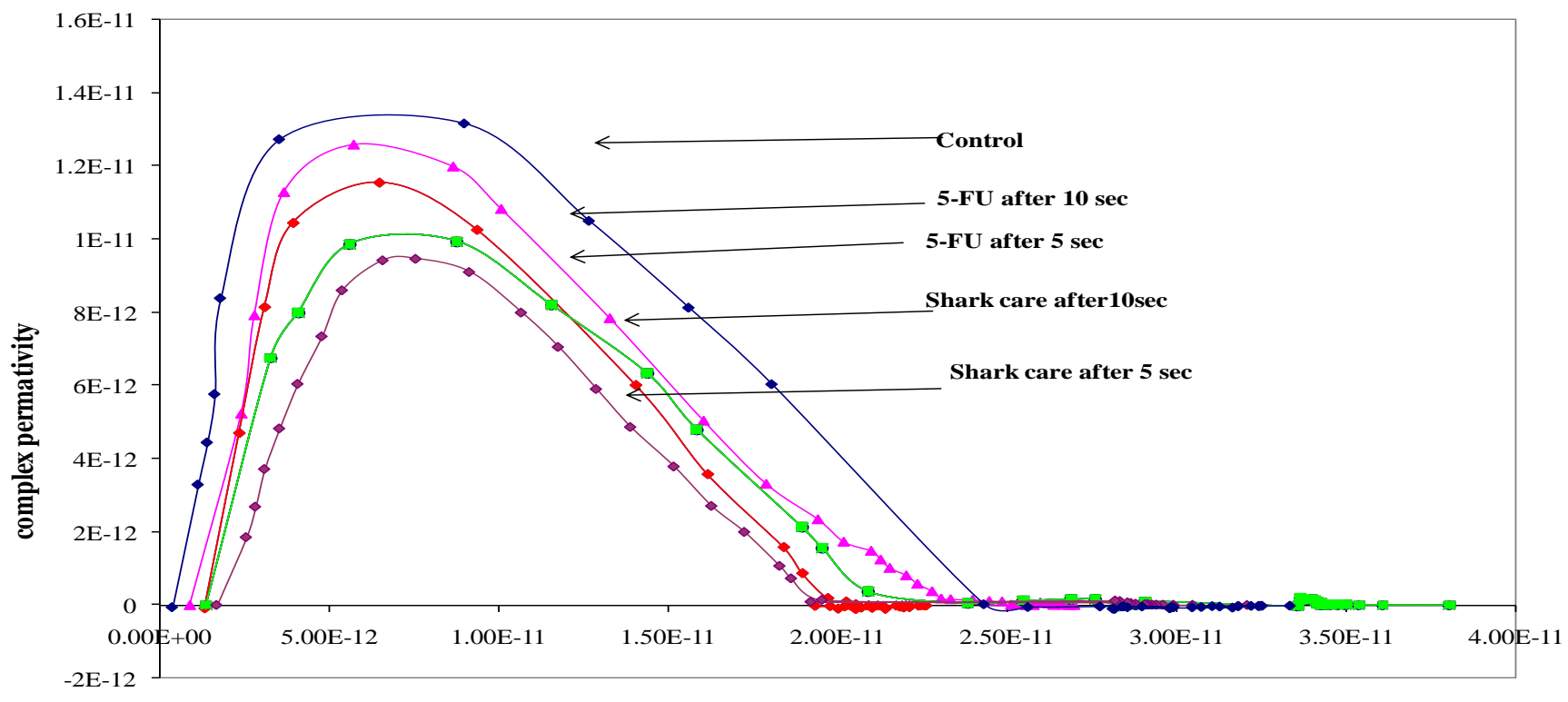

Relative permativity

Figure (17): The Complex permittivity diagram

The complex conductivity diagram Figure (18), follows the Cole - Cole semi circle pattern. The diagrams of gp (B-2-i) (group that treated by injected by $120 \mathrm{mg} / \mathrm{kg}$ of 5-Fluorouracil after exposed to electric field for $5 \mathrm{sec}$ ), gp (B-2 -ii) (group that treated by injected by $120 \mathrm{mg} / \mathrm{kg}$ of 5 Fluorouracil after exposed to electric field for 10 sec) are fare away than the control compared to the 
groups of gp (B-3-i) (group that treated by shark care drug dissolved in drinking water daily after exposed to electric field for $5 \mathrm{sec}$ ), and gp (B-3-ii) (group that treated by shark care drug dissolved in drinking water daily after exposed to electric field for $10 \mathrm{sec}$ ). Which are nerarest to the gp (A) (control) .

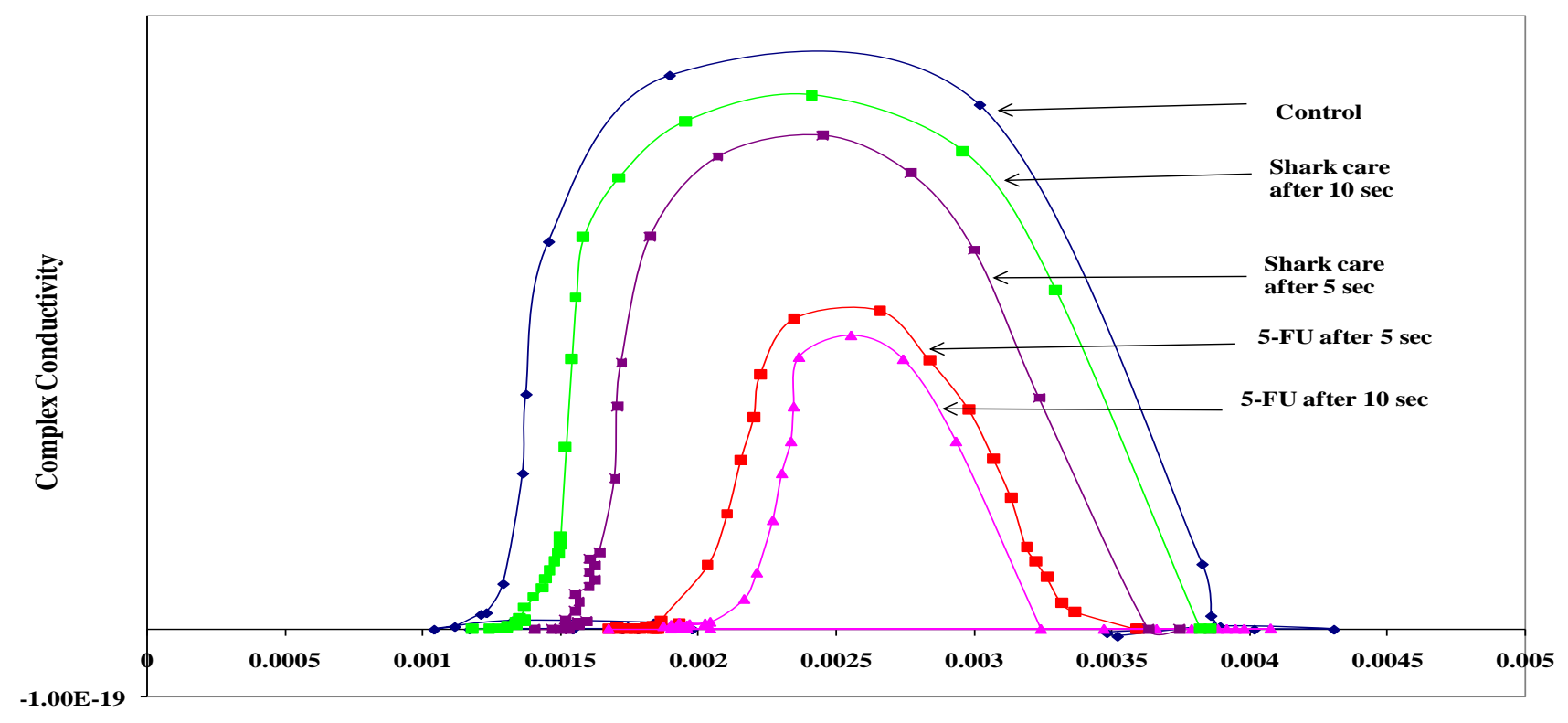

Conductivity

Figure (18): The complex conductivity diagram.

In the present study molecular study of AFP and TGF- $\beta 1$ gene expression as a molecular diagnostic and prognostic markers for $\mathrm{HCC}$ revealed a significant increase in the expression of AFP-mRNA and TGF- $\beta 1$-mRNA genes at sub group B1 after administration of DAB as compared to group $\mathrm{A}$, at the same time histopathological changes were also seen.

Sub group B3ii showed a relatively lower genes expression of AFP-mRNA and TGF- $\beta 1$ mRNA than B2ii and these reduction had its impact on the histopathological findings. This results indicated that treatment with shark care showed promising way for treatment of $\mathrm{HCC}$ than traditional chemotherapeutic 5-fluorouracil.

Sub group B3iii showed much lower genes expression of AFP-mRNA and TGF- $\beta 1-m R N A$ than B2iii and these reduction had its impact on the histopathological findings. This results revealed that electrical pulses-mediated drug delivery is gaining attention as a possible approach to enhance uptake of chemotherapy.

The data in the present study showed that during the whole course of experiment the histopathological changes were synchronized with the biochemical changes. Molecular detection of AFP-mRNA and TGF- $\beta 1$-mRNA genes expression using RT-PCR could be used as a diagnostic and prognostic predictor of $\mathrm{HC}$

\section{Discussion}

The application of pulsed fields has emerged as a local non-thermal and druge-free therapy for cancer. Pulsed electric field (PEF) therapy is a procedure using intense but short electric pulses that provoke either permanent permeabilization of cancer cells or destabilize the cell membranes and inteacellular components to which the cells are unable to repair resulting in their death. ${ }^{(17)}$ 


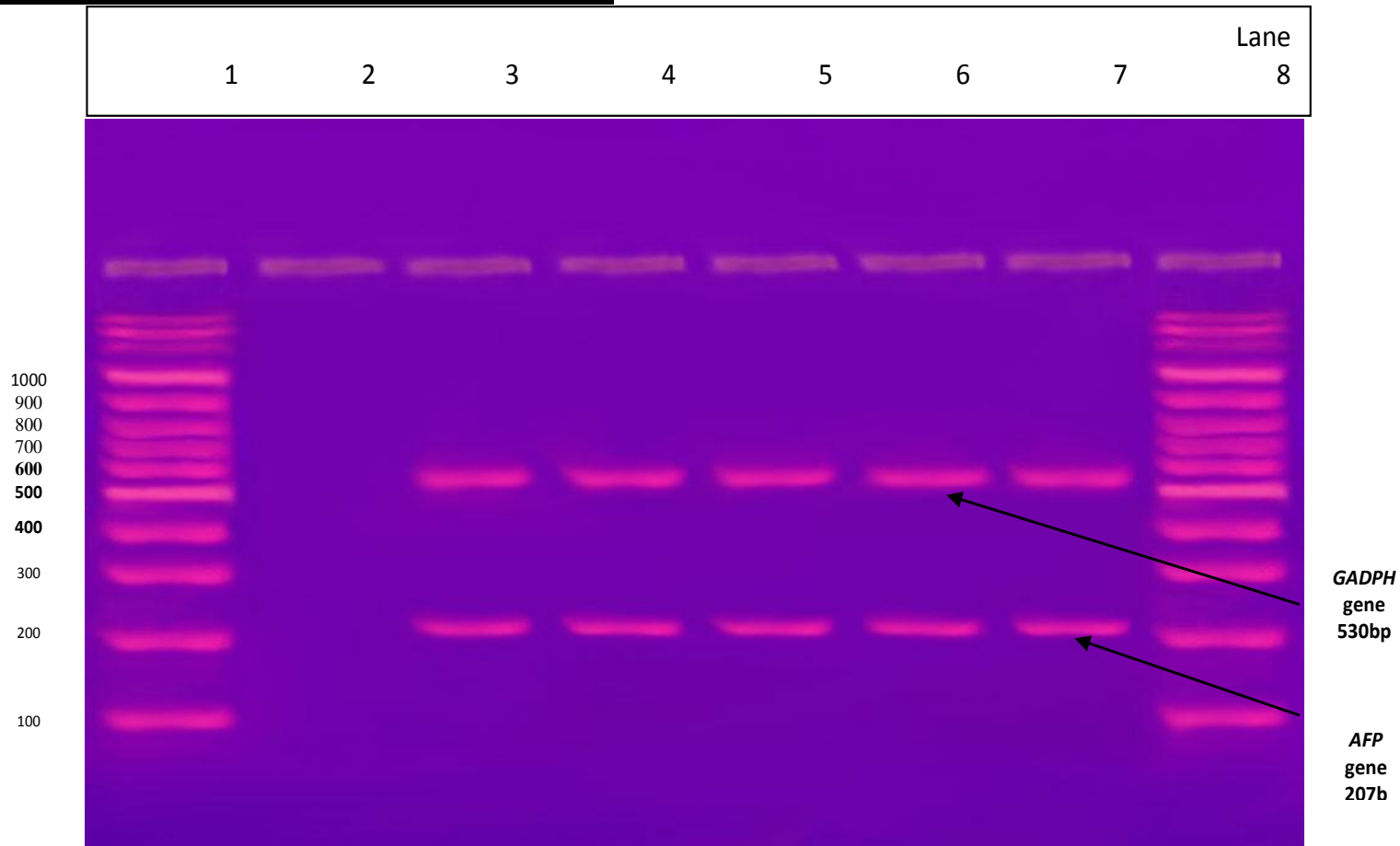

Figure (19): Ethidium bromide stained agarose gel showing bands of amplified PCR products of $m R N A$-AFP gene of Sub group B - 2i: 5 mice were injected intraperitoneal with $120 \mathrm{mg} / \mathrm{kg}$ body weight of 5-Fluorouracil dose every day for 21 days blood samples: Lane 1 and 8 marked the DNA marker, Lane 2 showing negative control (DNA nuclease free water), , lane 3- 7 marked positive cases showing amplified bands of $207 \mathrm{bp}$. (530 bp representing GADPH gene as positive control).

\section{Amplification of mRNA-AFP gene by RT-PCR:}

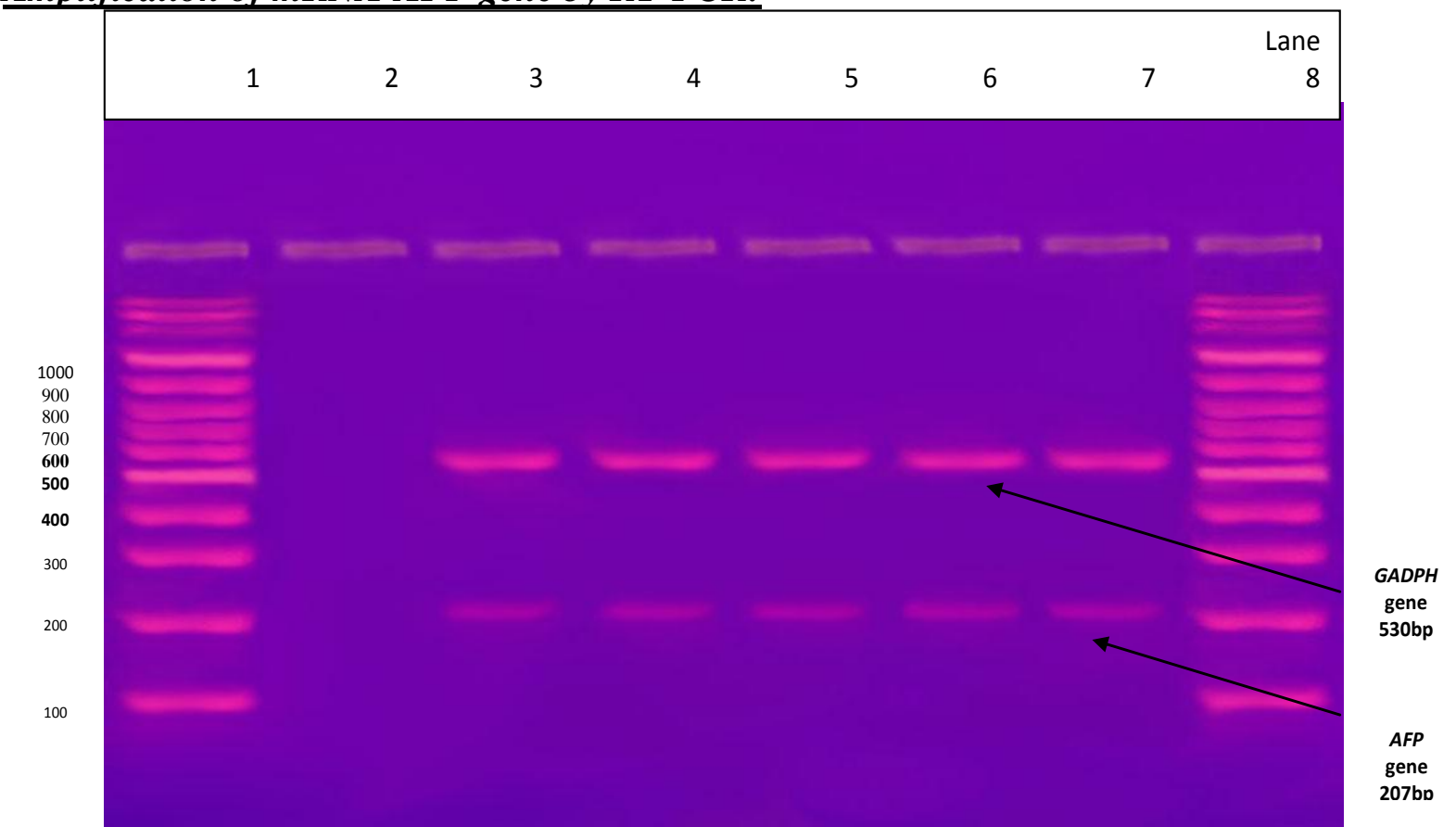

Figure (20): Ethidium bromide stained agarose gel showing bands of amplified PCR products of $m R N A-A F P$ gene of Sub group B - 2ii: 5 mice were injected intraperitoneal with $120 \mathrm{mg} / \mathrm{kg}$ body weight of 5 -Fluorouracil dose every day for 21 days and were exposed to(LG1100) MCP corp for $5 \mathrm{sec}$ blood samples: Lane 1 and 8 marked the DNA marker, Lane 2 showing negative control (DNA nuclease free water), , lane 3- 7 marked positive cases showing amplified bands of $207 \mathrm{bp}$. (530 bp representing GADPH gene as positive control). 


\section{Amplification of mRNA-AFP gene by RT-PCR:}

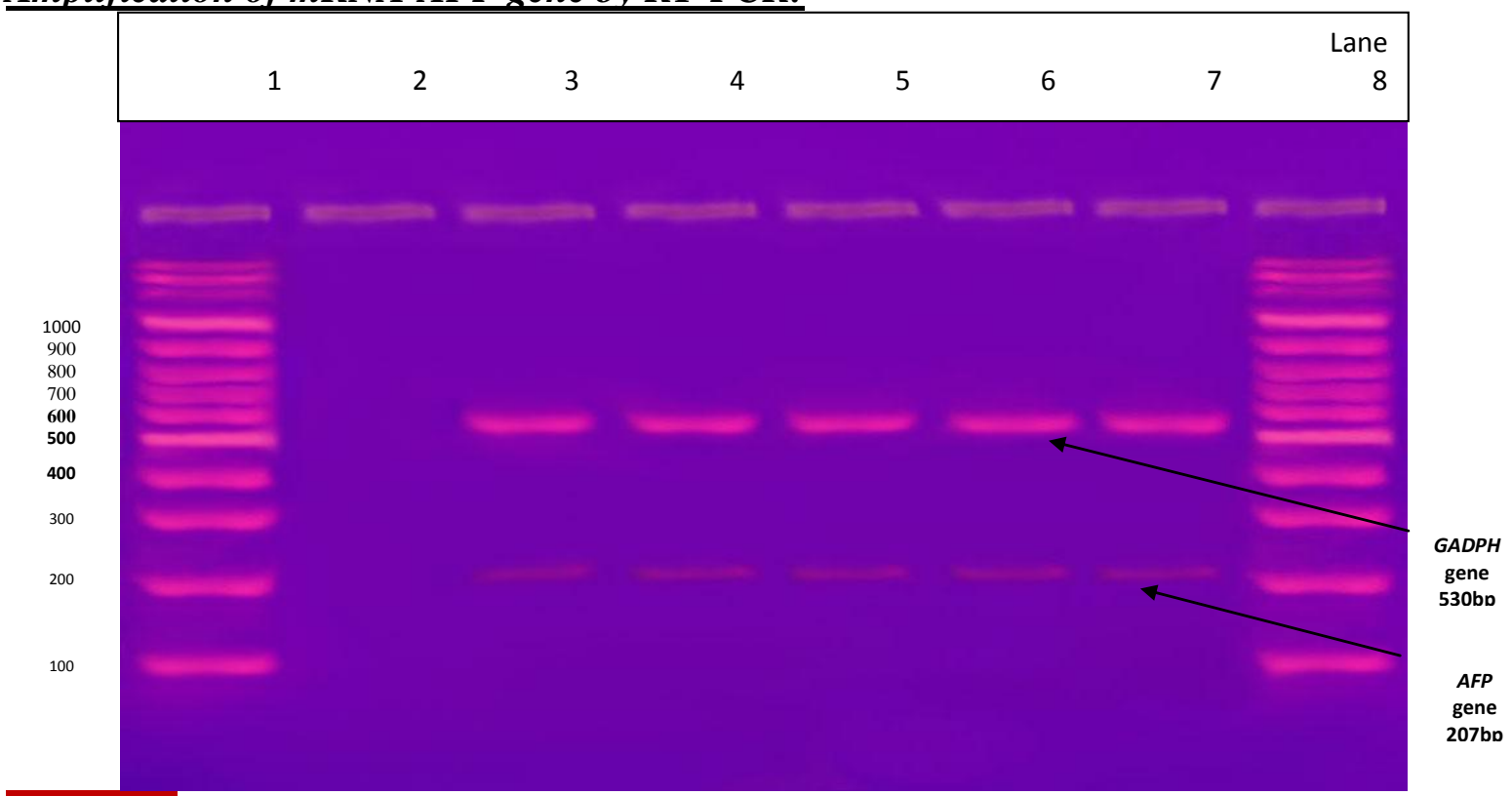

Figure (21): Ethidium bromide stained agarose gel showing bands of amplified PCR products of $m R N A-A F P$ gene of Sub group B - 2iii: 5 mice were injected intraperitoneal with $120 \mathrm{mg} / \mathrm{kg}$ body weight of 5-Fluorouracil dose every day for 21 days and were exposed to(LG1100) MCP corp for $10 \mathrm{sec}$ blood samples: Lane 1 and 8 marked the DNA marker, Lane 2 showing negative control (DNA nuclease free water), , lane 3- 7 marked positive cases showing amplified bands of $207 \mathrm{bp}$. (530 bp representing GADPH gene as positive control).

\section{Amplification of mRNA-AFP gene by RT-PCR:}

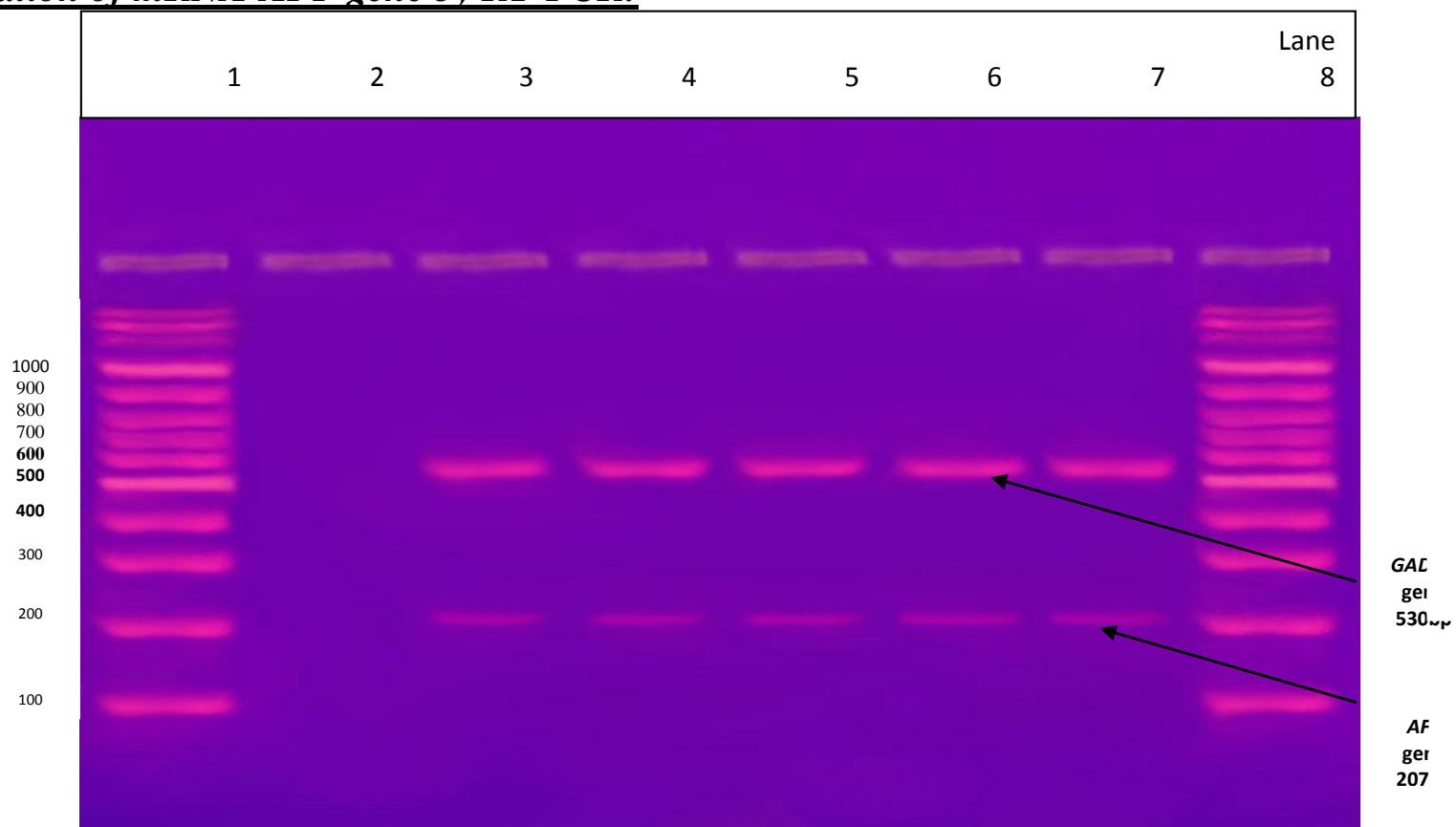

Figure (22): Ethidium bromide stained agarose gel showing bands of amplified PCR products of $m R N A$-AFP gene of Sub of group B - 3ii: 5 mice were treated by shark care drug dissolved in drinking water daily for 21 days and were exposed to(LG1100) MCP corp for $5 \mathrm{sec}$ blood samples: Lane 1 and 8 marked the DNA marker, Lane 2 showing negative control (DNA nuclease free water), , lane 3- 7 marked positive cases showing amplified bands of 207 bp. (530 bp representing GADPH gene as positive control). 


\section{Amplification of mRNA-AFP gene by RT-PCR:}

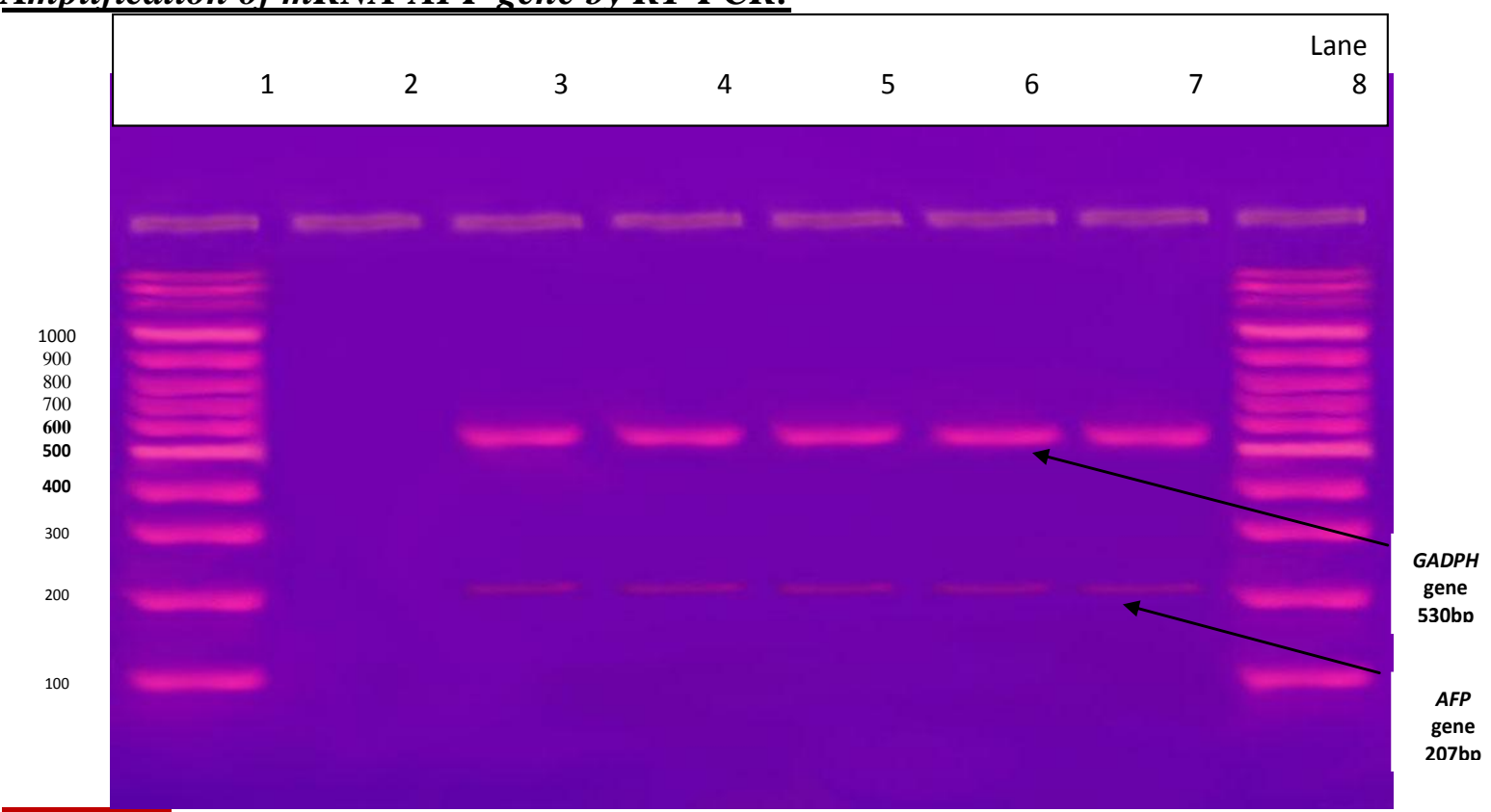

Figure (23): Ethidium bromide stained agarose gel showing bands of amplified PCR products of $m R N A$-AFP gene of Sub of group B - 3iii: 5 mice were treated by shark care drug dissolved in drinking water daily for 21 days and were exposed to(LG1100) MCP corp for $10 \mathrm{sec}$ blood samples: Lane 1 and 8 marked the DNA marker, Lane 2 showing negative control (DNA nuclease free water), , lane 3- 7 marked positive cases showing amplified bands of 207 bp. (530 bp representing $G A D P H$ gene as positive control).

\section{Amplification of mRNA-TGFB1 gene by RT-PCR:}

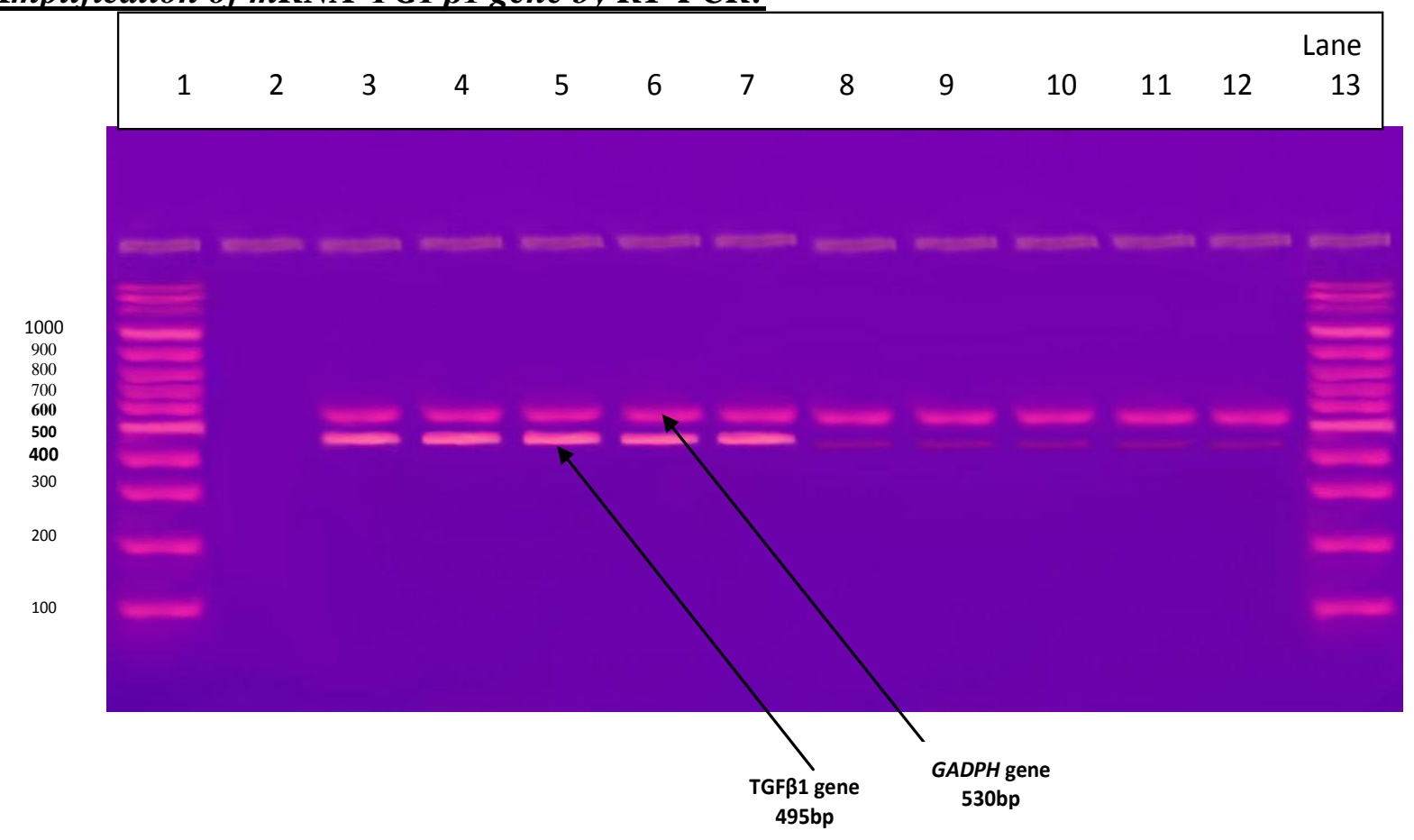

Figure (24): Ethidium bromide stained agarose gel showing bands of amplified PCR products of $m R N A-T G F \beta 1$ gene of Sub group B -1; mice have induced HCC by DABE and have not received any treatment blood samples: Lane 1 and 13 marked the DNA marker, Lane 2 showing negative control (DNA nuclease free water), lane 3- 7 marked positive cases showing amplified bands of $495 \mathrm{bp}$ and lane 8- 12 marked positive cases of control group mice (530 bp representing $G A D P H$ gene as positive control). 


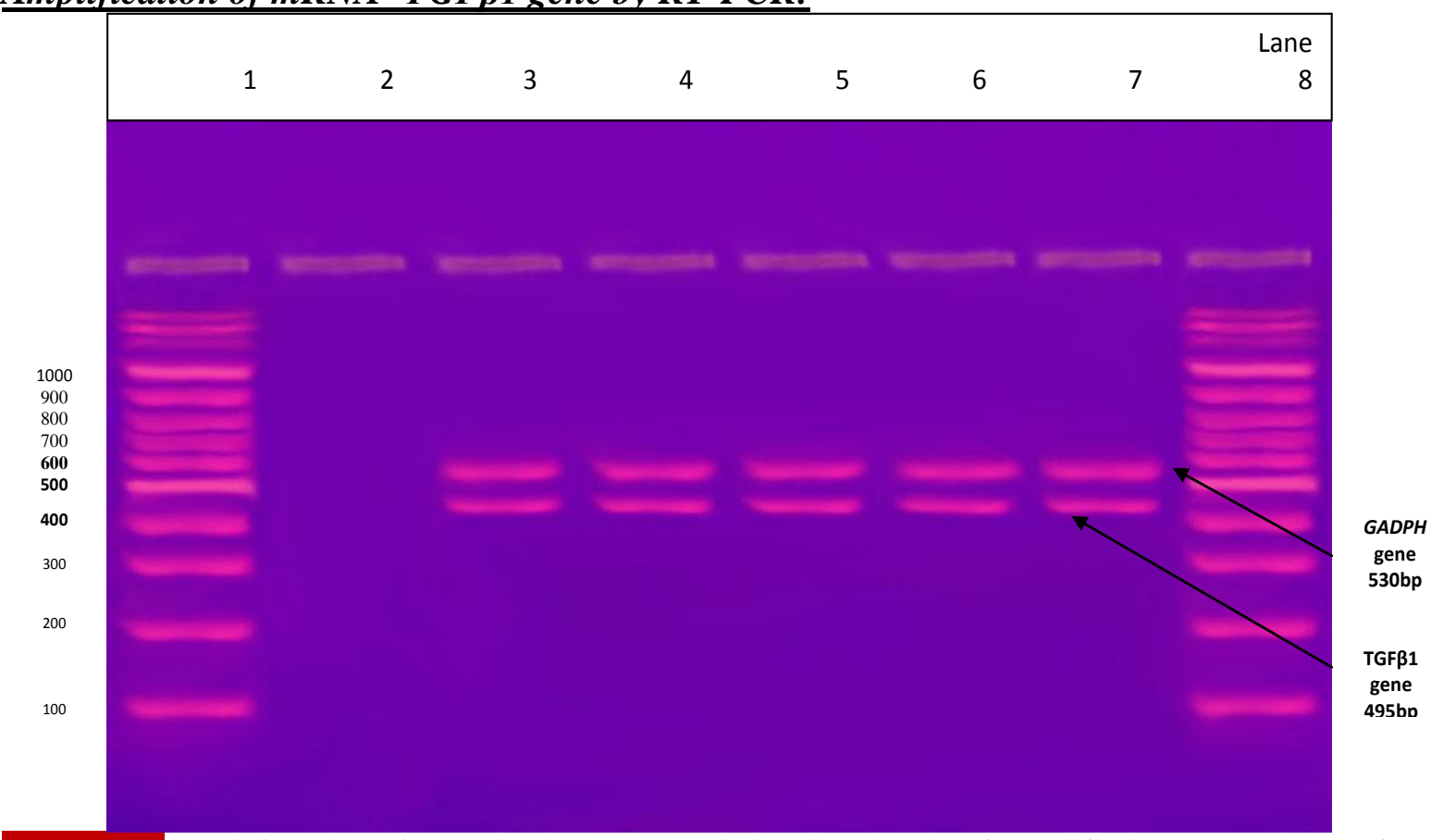

Figure (25): Ethidium bromide stained agarose gel showing bands of amplified PCR products of $m R N A-T G F \beta 1$ gene of Sub group B - 2i: 5 mice were injected intraperitoneal with $120 \mathrm{mg} / \mathrm{kg}$ body weight of 5-Fluorouracil dose every day for 21 days blood samples: Lane 1 and 8 marked the DNA marker, Lane 2 showing negative control (DNA nuclease free water), , lane 3- 7 marked positive cases showing amplified bands of $495 \mathrm{bp}$. (530 bp representing GADPH gene as positive control).

\section{Amplification of mRNA- TGFB1 gene by RT-PCR:}

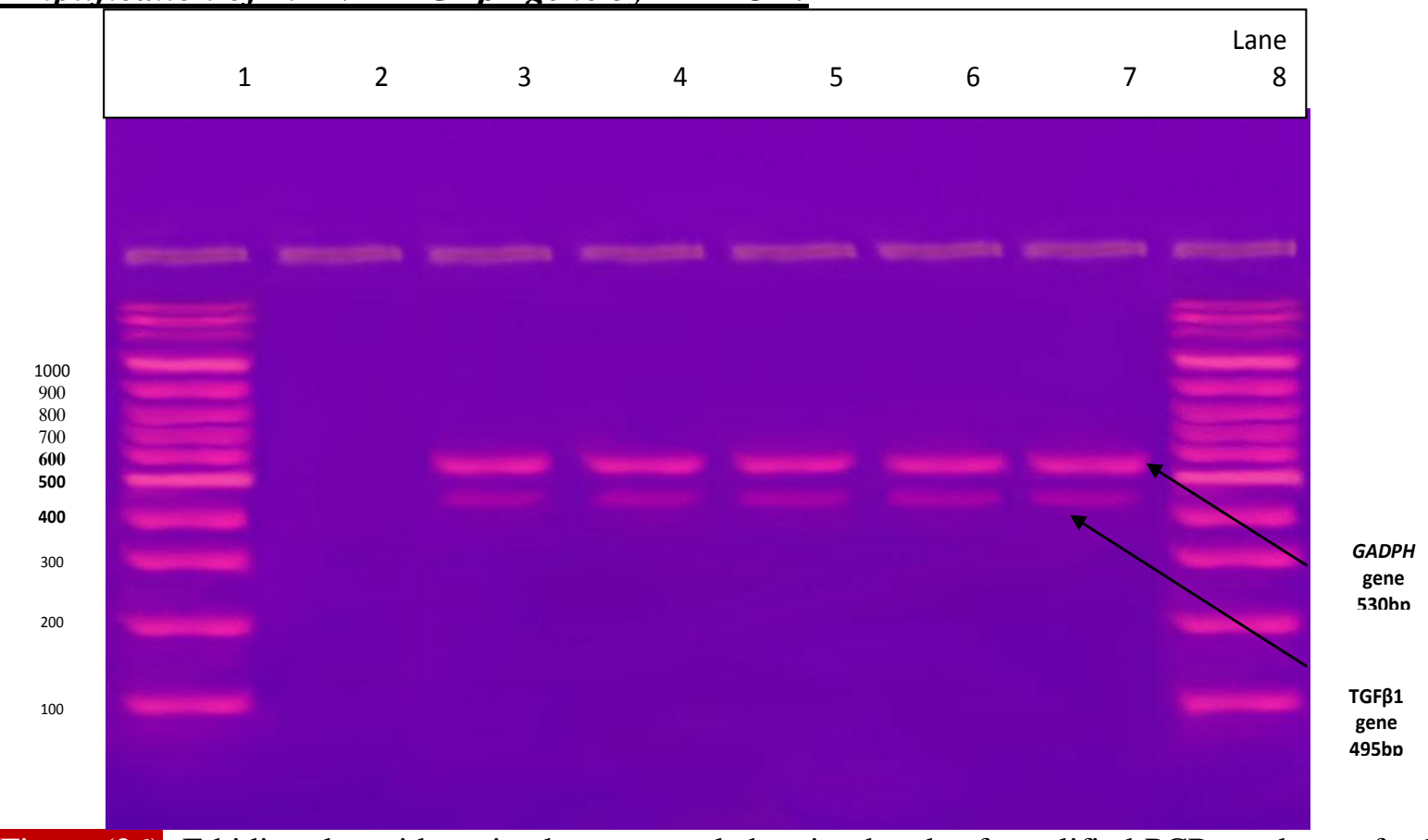

Figure (26): Ethidium bromide stained agarose gel showing bands of amplified PCR products of $m R N A$ - TGFB1 gene of Sub group B - 2ii: 5 mice were injected intraperitoneal with $120 \mathrm{mg} / \mathrm{kg}$ body weight of 5-Fluorouracil dose every day for 21 days and were exposed to(LG1100) MCP corp for $5 \mathrm{sec}$ blood samples: Lane 1 and 8 marked the DNA marker, Lane 2 showing negative control (DNA nuclease free water), , lane 3- 7 marked positive cases showing amplified bands of $495 \mathrm{bp}$. (530 bp representing GADPH gene as positive control). 


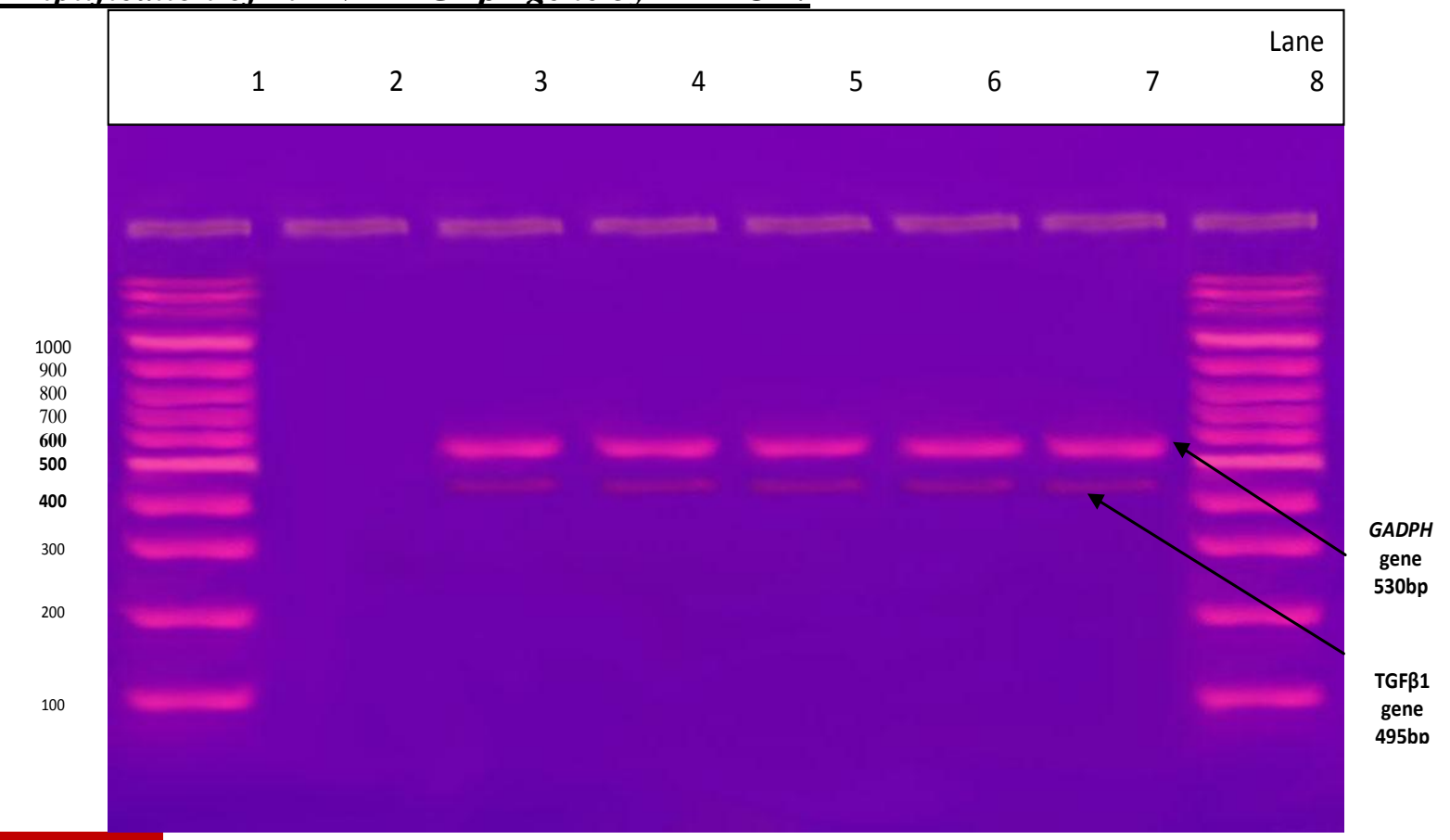

Figure (27): Ethidium bromide stained agarose gel showing bands of amplified PCR products of $m R N A-T G F \beta 1$ gene of Sub group B - 2iii: 5 mice were injected intraperitoneal with $120 \mathrm{mg} / \mathrm{kg}$ body weight of 5-Fluorouracil dose every day for 21 days and were exposed to(LG1100) MCP corp for $10 \mathrm{sec}$ blood samples: Lane 1 and 8 marked the DNA marker, Lane 2 showing negative control (DNA nuclease free water), , lane 3- 7 marked positive cases showing amplified bands of $495 \mathrm{bp}$. (530 bp representing GADPH gene as positive control).

\section{Amplification of mRNA-TGFß1 gene by RT-PCR:}

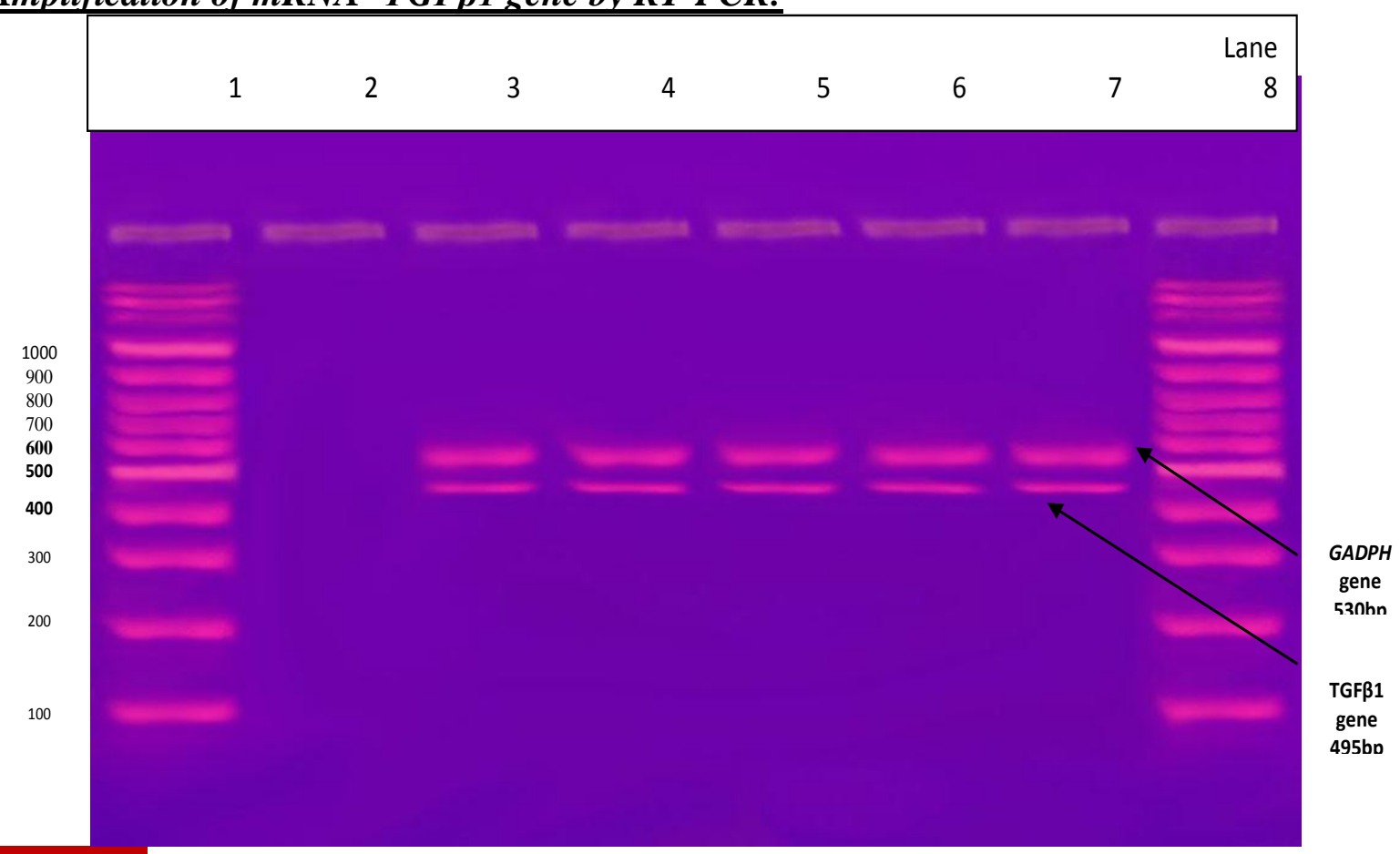

Figure (28): Ethidium bromide stained agarose gel showing bands of amplified PCR products of $m R N A-T G F \beta 1$ gene of Sub of group B - 3i: 5 mice were treated by shark care drug dissolved in drinking water daily for 21 days blood samples: Lane 1 and 8 marked the DNA marker, Lane 2 showing negative control (DNA nuclease free water), , lane 37 marked positive cases showing amplified bands of $495 \mathrm{bp}$. (530 bp representing GADPH gene as positive control). 


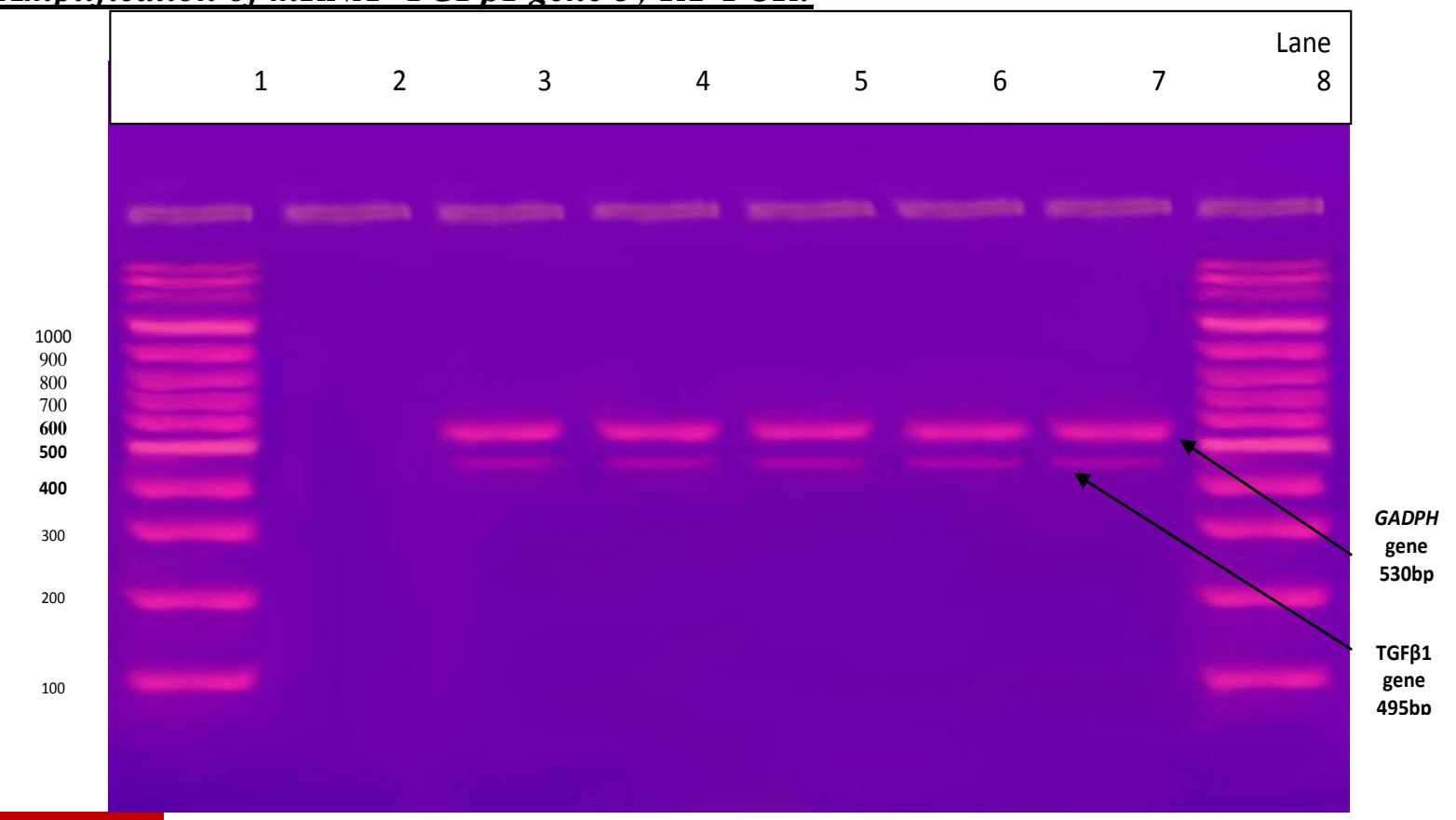

Figure (29): Ethidium bromide stained agarose gel showing bands of amplified PCR products of $m R N A-T G F \beta 1$ gene of Sub of group B - 3ii: 5 mice were treated by shark care drug dissolved in drinking water daily for 21 days and were exposed to(LG1100) MCP corp for $5 \mathrm{sec}$ blood samples: Lane 1 and 8 marked the DNA marker, Lane 2 showing negative control (DNA nuclease free water), , lane 3- 7 marked positive cases showing amplified bands of $495 \mathrm{bp}$. (530 bp representing GADPH gene as positive control).

\section{Amplification of mRNA-TGFB1 gene by RT-PCR:}

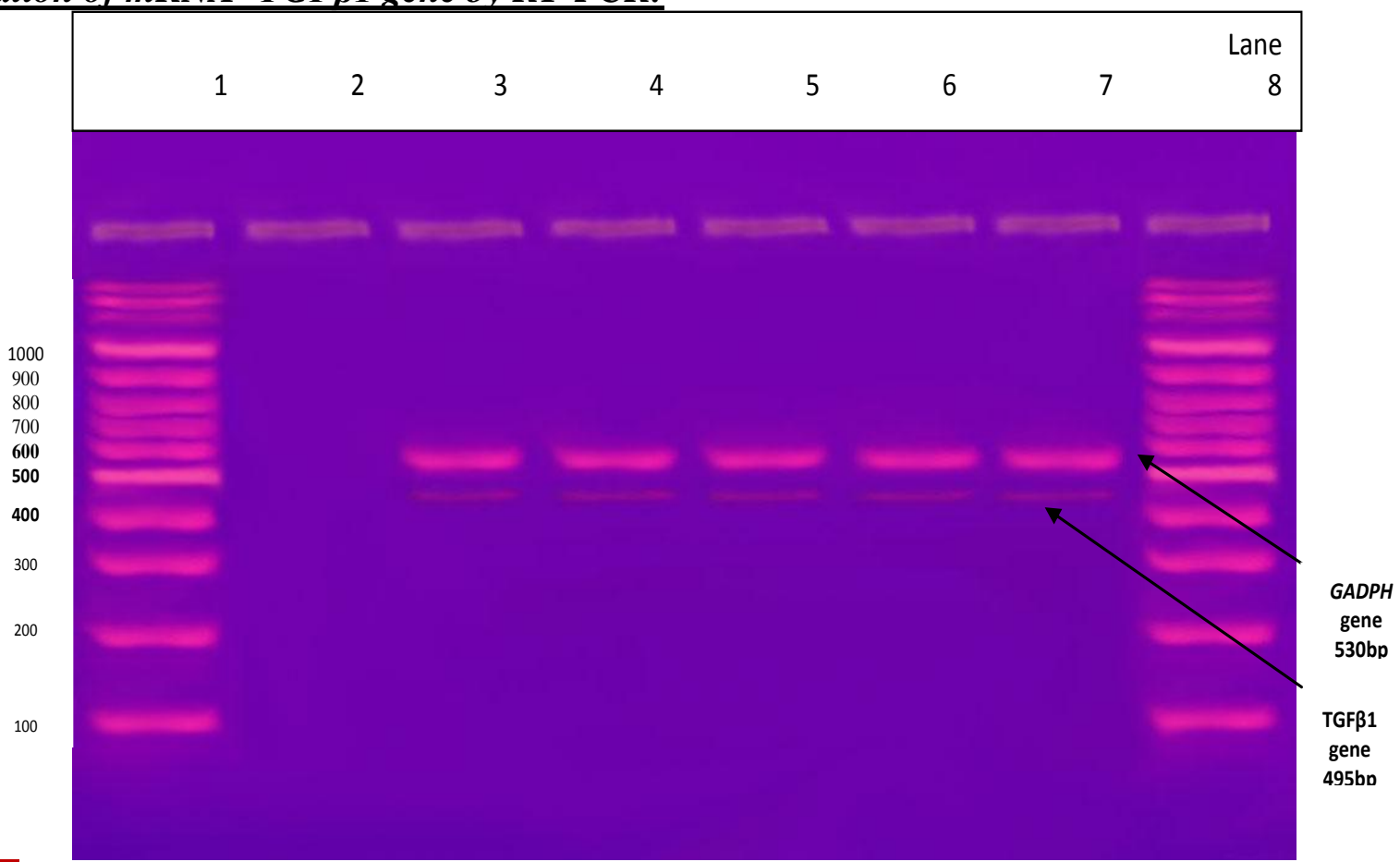

Figure (30): Ethidium bromide stained agarose gel showing bands of amplified PCR products of $m R N A$ - TGF 1 gene of Sub of group B - 3iii: 5 mice were treated by shark care drug dissolved in drinking water daily for 21 days and were exposed to(LG1100) MCP corp for $10 \mathrm{sec}$ blood samples: Lane 1 and 8 marked the DNA marker, Lane 2 showing negative control (DNA nuclease free water), , lane 3- 7 marked positive cases showing amplified bands of $495 \mathrm{bp}$. (530 bp representing $G A D P H$ gene as positive control). 
The effects of pulsed electric fields on biological cells and tissues have been the topic of research for many years. The earlist report of bioleffects arsing from the direct application of voltage using contact techniques (as opposed to contractess exposure using electomagnetic radition) was when Stampfli and Willi reported on electric induced changes of cell memebranes in 1957. In particular they measured changes in membrane conducctivity and membrane potential. They further found that memebrane damage is irreversible if the applied electric pulses are longer but otheraise the membrane is restored to its original characterisitc. Almost a decade later, damaging effects of strong electric field on bacteria were reported suggesting nonthermal membrane interactions. Subsequent experiments showed that strong electric field pulses caused the increase in permeability of the plasma membrane of a bilogical cell. ${ }^{(17)}$

The relative high control value of cell membrane permittivity $(\epsilon)$ and conductivity $(\sigma)$ may be attributed to the high value of the membrane capacitance and conductance due to normal value of cell membrane potential and distribution of ions dipoles. So the low values of the membrane permittivity and conductivity may be due to the lipid peroxidation, which causes cell membrane damage, cell death. ${ }^{(17)}$

Decreasing in the real permittivity for the group treated by 5- Fluorouracil as the time increase indicates that the degree of hepatic healing or therapy seem to be time - dependent the increasing in the real permittivity for the group treated by shark care for $5 \mathrm{sec}$ in comparsion with the same group treated with 5Fluorouracil may be resulted from a rise in membrane capacitance due to the increase in membrane surface resulting from cell swelling. ${ }^{(18)}$

Beebe and coworkers first showed that appling ultrashort, pulsed electric fields (PEF) to mammalian cells and solid tumors results in reduced tumor growth, and induction of apoptosis in the treated cells. ${ }^{(19,20)}$ Anumber of studies have confirmed these observations, showing that PEFs do induce apoptosis in a number of cancer cell type in vitro and tumors in vivo.

The proposals of using pulsed electric fields to pursure the treatment of cancer free of cytotoxic druges and to achieve selective killing of tumor cells by inducing apoptosis is worthwhile to examine. Many cancers were resistant to current tratments and there was an urgent need for therapeutic innovations and discovery. There were currently three pulsed electric field therapies being tested on various tumor types in animals and preclinical studies. The aim of these minimally invasive treatments was to limit surgery and reduce side effects, scarring, pain, and mortality of patients while remaining costeffective and safe. This review provides a brief overview of these therapies and their current stage in clinical research.

Tissue is a high in homogenous material it is obvious that interfacial processes play an important role in the electricalproperties of tissue. This can be explained from figures (7-16) which illustrated the variation of permittivities and conductivities of the trated either by 5Fluorouracil for 5 and $10 \mathrm{sec}$ or by shark care for $5,10 \mathrm{sec}$ respectively. The high permittivity values of the HCC mice group treated either by 5Fluorouracil or shark care at low frequency level are correlated with Fricke \& Morse ${ }^{(21)}$ and these can be attributed to change in cellular water content the amount of extra-cellular fluid, membrane properties, to change in the orientationof the malignant cells.

The cell plasma membrane consists of lipid bilayer with a thickness of approximately $5 \mathrm{~nm}$. Its function is to protect the cell interior but also to facilitate the flow of selected types of ions and other materials from and to its surroundings. Under physiological conditions, the plasma membrane is subjected to a voltage difference caused by a system of ion pumps and channels in the membrane. Bioelectric fields are present whenever there is a potential difference between two regions in an organism. Every cell inour body generates this electric potenial difference across the plasma membrane termed the resulting transmembrane voltage that is about $70 \mathrm{mv}$, inside negative. ${ }^{(22)}$ In biophysics, cell membrane represent nonconducting, dielectric barriers and function as a near-ideal capacitor that can easily be charged by appling an external voltage pulse. (23) Consequently, large localized electric field 
can be created across membranes that can then drive a host of bioeffects.

The exposure of a cell to an externally applied electric field results in an additional component of the voltage across the membrane. (24) This component, termed the induced transmembrane voltage, is superimposed onto the resulting voltage and exists only as long as the external field was present. With the accumulation of ions along the cell membrane, the potential difference across the membrane increase and the electric field inside the cell is reduced simultaneouly. ${ }^{(25)}$ The induced transmembrane voltage is proortional to the strength of the external electric field, and exposures to sufficiently strong fields can lead to transmembrane voltages far exceeding their physilogical range. (26) Such large electric fields will exert a force on charged molecules such as water dipoles and can drive water into the lipid membrane to form a water-field defect or pore through the bilayer. (27) Such pores will allow the movement of small molecules across the membrane. This phenomenon was termed electroporation, or electropermeabilization. (28-30) The possibility of curing electric pulses in cancer therapy may also rely on the different responses between cancers calls and normal cells. Cancer cells would have a higher apoptosis percentage than normal cells when exposed to the same electric field. (31) And this finding are in agrements with our work that is to say that with incrasing the time of the exposure to electric field the values of the permittivity show the higher value than it corresponding value at the same frequency.

The electric fields that are requried to achieve cell death depend on the duration of the applied pulse, since this process involves the gradual changing of the capacitive sheath followd by the molecular rearrangment of the lipids. ${ }^{(32)}$ These parameters of electric pulses play major roles in the type of effect on targeted cells. The PEFbased techniques creating irreversible cellular damage are drivided in accordance to the pulse length hereafter. Their medical translations into cancer therapies are named irreversible electroporation (IRE).

Electrochemotherapy uses conventional electroporation with electric field durations in the micro- to millisecond range this causes transient defects in plasma membrane, allowing the entry of poorly permeable druge such as bleomycin to ablate tumors. Experimentally, the parameters that mainly influence the size of the ablated zone were the pulse amplitude, pulse duration, number of pulses, and to a lesser extent pulse repetition frequency of pulses. By modulating the parameters of the pulses as suggested by Davalos and coworkers it is possible to obtain a transmembrane potential high enough to ensure permanent permeabilization. ${ }^{(33)}$ It has been found that the shorter the pulses, the higher the field strength necessary to observe the biological effects. ${ }^{(34)}$ When a voltage gradient is applied long enough to a cell, chargeds accumulate at the plasma membrane creating an electric gradient across the membrane this transmembrane potential depends on the electric field amplitude. The most optimal parameters are being determined in vivo research and many differ per cancer type. For instance, $40 \mathrm{KV} / \mathrm{cm}$ electric pulses have been used to treat melanomas ${ }^{(35)}$ or 35,50 and $68 \mathrm{KV} / \mathrm{cm}$ to treat hepatocellular cancer. ${ }^{(36)}$

The larger the pulse number and the electric field, the larger will be the permeability increase in the plasma membrane. ${ }^{(37)}$ Plasma membrane permeabilization may not be the only primary bioeffect of electric pulses. A number of studies by Chen and Co-authors indicated that electric pulses of supra-physiological voltage could cause damage to voltage gated (VG) ion channels (38-40) or maybe by inhibition og VG ion channels as suggested in a study by Nesin and colleagues. ${ }^{(41)}$ Phosphatidylserine externalization inducating induction of apoptosis has been observed as well. Such result indicated the importance of the electric field in enhancing the effect of the chemotherapeutic agent (5-FU) in our work. ${ }^{(42)}$

HCC exhibits numerous molecular abnormalities, which may be involved in the process of HCC development and progression. Thus, it is important to identify accurate predictors of prognosis and a reasonable selection criterion that can be applied to patients with HCC, particularly with early stage HCC, for rational treatment decisions remains a challenging task. ${ }^{(43)}$ During the diagnosis of 
HCC, a combination assay of at least two or three markers is recommended for a more sensitive and specific diagnosis of HCC. However, these traditional biomarkers do not reflect the biological features of the tumor or provide information about HCC behavior; thus, they do not allow the physician to accurately predict the outcomes of HCC patients. In the emerging era of new molecular targeted therapy for HCC, the evaluation of these novel agents will also require novel improvements in both the efficacy of the traditional biomarkers as well as other serological markers.

In the present study molecular study of AFP and TGF- $\beta 1$ gene expression as a molecular diagnostic and prognostic markers for HCC revealed a significant increase in the expression of AFP-mRNA and TGF- $\beta 1$-mRNA genes at sub group $\mathrm{B} 1$ after administration of $\mathrm{DAB}$ as compared to group $\mathrm{A}$, at the same time histopathological changes were also seen.

The data in the present study showed that during the whole course of experiment the histopathological changes were synchronized with the biochemical changes. According to current results, there were an agreement with other studies done by several authors. (43-50) Finally our study further support that molecular detection of AFP-mRNA and TGF- $\beta 1-m R N A$ genes expression using RT-PCR could be used as a diagnostic and prognostic predictor of HCC.

\section{Conclusion}

From the present study it could be suggested that therapeutic effect of shark care drug showed promising results for treatment of HCC compared to results obtained with 5-Fluorouracil drug. presence of electric field results in reduced tumor growth, and induction of apoptosis in the treated cells by enhanceing uptake of chemotherapy and delivering anticancer drugs with enhanced efficacy and fewer adverse effects.

\section{Recommendation}

From the present study it could be recommended that use of shark care drug for treatment of HCC with increasing duration of treatment course. Also use of electric field for enhanceing uptake of chemotherapy and delivering anticancer drugs with enhanced efficacy and fewer adverse effects.

\section{References}

1. Bosch FX, Ribes J, Cleries R, Diaz M. Epidemiology of hepatocellular carcinoma. Clin Liver Dis (2005); 9: 191-211. DOI: 10.1016/j.cld.2004.12.009

2. Yu MC, Yuan JM, Govindarajan S, Ross RK. Epidemiology of hepatocellular carcinoma. Can J Gastroenterol (2000); 14:703-9.

3. Lim SO, Park SJ, Kim W, Park SG, Kim HJ, Kim YI, et al. Proteome analysis of hepatocellular carcinoma. Biochem Biophys Res Commun (2002); 291(4):1031-7. DOI: 10.1006/bbrc.2002.6547

4. Reynolds JE. Martindale the Extra Pharmacopoeia. $31^{\text {st }}$ ed. The Royal Pharmaceutical Society, London(1996).

5. Berndtsson $\mathrm{M}$, Hagg $\mathrm{M}$, Panaretakis $\mathrm{T}$, Havelka AM, Shoshan MC, Linder S. Acute Apoptosis by cisplatin requires induction of reactive oxygen species but is not associated with damage to nuclear DNA. Int $\mathbf{J}$ Cancer (2007); 120(1):175-80. DOI: 10.1002/ijc.22132

6. Mookerjee A, Basu JM, Majumder S, Chatterjee S, Panda GS, Dutta P, et al. A novel copper complex induces ROS generation in doxorubicin resistant Ehrlich ascitis carcinoma cells and increases activity of antioxidant enzymes in vital organs in vivo.BMC Cancer (2006); 6:267-78. DOI: 10.1186/1471-2407-6-267

7. Tuorkey MJ, Abdul-Aziz KK. A pioneer study on the anti-ulcer activities of copper nicotinate complex $\left[\mathrm{CuCl}(\mathrm{HNA})_{2}\right]$ in experimental gastric ulcer induced by asprinpyloris ligation model(Shay model). Biomed Pharmacother (2009); 63(3):194-201. DOI: 10.1016/j.biopha.2008.01.015

8. El-Saadani MA. A combination therapy with copper nicotinate complex reduces the adverse effects of 5-fluorouracil on patients 
with hepatocellular carcinoma. J Exp Ther Oncol (2004): 4(1):19-24.

9. Benet LZ, Kroetz DL, Sheiner LB: Pharmacokinetics: the dynamics of drug absorption, distribution, and elimination. In: Hardman JG, Limbird LE, Molinoff PB, Ruddon RW, ed. Goodman \& Gilman s the pharmacological Basis of Therapeutics, 9th ed.. New York: McGraw-Hill; (1996), pp. 327.

10. Uzzan B, Nicolas P, Cucherat M, Perret G. Microvessel Density as a prognostic Factor in Women with breast cancer: A systematic Review of the Literature and Meta-Analysis. Cancer Research (2004); 64: 2941-55. DOI: 10.1158/0008-5472.CAN-03-1957

11. Lewis JV. Illustrated Guide to Diagnostic Tests: Student Version. Springhouse, PA: Springhouse Corp (pub); (1994). P. 578-645.

12. Gingras D, Renaud A, Mousseau N and Beliveau R, Shark cartilage extracts as antiangiogenic agents: Smart drinks or bitter pills? Cancer Metast Rev (2000); 19: 83-6. DOI: 10.1023/A:1026504500555

13. Li H, Forstermann U. Nitric oxide in the pathologenesis of vascular disease. J Pathol, (2000): 190:244-54. DOI: 10.1002/(SICI)10969896(200002)190:3<244::AID-PATH575>3.0.CO;2-8

14. Polk, C. and potow, E.,"Handbook of Piological Effects of Electromagnetic Field" .CRC Press, Inc.Tokyo (1996).

15. Irimajiri, A, Asmi, K. and Kinoshita, Y., Passive electrical properties of the membrane and cytoplasm of cultured rat basophile leukaemia, Biochemica et biophysica Acta (1987); 86-203.

16. Irimajiri,A ,Asmi, K. and Kinoshita, Y., and Takashima, S., Dielectric properties of mouse lymphocytes and erythrocytes. Biochemica et Biophysica Acta.(1988); 1010:49.

17. O Shea JJ,Paul WE.Regulation of $\mathrm{T}(\mathrm{H}) 1$ differentiation controlling the controllers Nat Immunol 2002;3(6):506-8. DOI: 10.1038/ni0602-506

18. Hammerich D., Ozkan O.R., Tsai J-Z., Staelin S.T., Tungiitkusolmum S., Mahvi D.M., Webster J.G.,Changes in electric resistivity of swine liver after occlusion and postmortem Med. Biol.Eng. comput 2002;40:29-33. DOI: 10.1007/BF02347692
19. Beebe SJ, Fox P, Rec LJ, Somers K, Stark RH, Schoenbach KH. Nanosecond pulsed electric field (nsPEF) effects on cells and tissues: Apoptosis induction and tumor growth inhibition. IEEE Transactions on Plasma Science. (2002); 30(1):286-92. DOI: 10.1109/TPS.2002.1003872

20. Beebe SJ, White J, Blackmore PF, Deng Y, Somers K, Schoenbach KH. Diverse effects of nanosecond pulsed electric fields on cells and tissues. DNA Cell Biol.( 2003);22:78596. DOI: $10.1089 / 104454903322624993$

21. Frick H, and Morse S., the electric capacity of tumors of the breast. J.cancer Res.(1982); 20:422.

22. Altunc S, Baum CE, Christodoulou CG, Schamiloglu E. Spatially Limited Exponential Lens Design for Better Focusing an Impulse. Proc. URSI General Assembly. August (2008), Chicago, IL.

23. Joshi RP, Hu Q. Case for applying subnanosecond high-intensity, electrical pulses to biological cells. IEEE Trans Biomed Eng. (2011);58(10):2860-6. DOI: 10.1109/TBME.2011.2161478

24. Schoenbach KH, Hargrave B, Joshi RP, Kolb JF, Osgood C, Nuccitelli R, Pakhomov A, Swanson RJ, Stacey M, White JA, Xiao S, Zhang J, Beebe SJ, Blackmore PF, Buescher ES. Bioelectric effects of intense nanosecond pulses. IEEE Trans. Dielect. Electr. Insul. (2007);14(5):1088-1119. DOI: 10.1109/TDEI.2007.4339468

25.Swanson RJ, Stacey M, White JA, Xiao S, Zhang J, Beebe SJ, Blackmore PF, Buescher ES. Bioelectric effects of intense nanosecond pulses. IEEE Trans. Dielect. Electr. Insul. (2007);14(5):1088-1119.

DOI: 10.1109/TDEI.2007.4339468

26. Joshi RP, Song J, Schoenbach KH, Sridhara V. Aspects of lipid membrane bio-responses to subnanosecond, ultrahigh voltage pulsing. IEEE Trans. Dielectr Electr Insul (2009);16(5):1243-50. DOI: 10.1109/TDEI.2009.5293934

27. Joshi RP, Song J, Schoenbach KH, Sridhara V. Aspects of lipid membrane bio-responses to subnanosecond, ultrahigh voltage pulsing. IEEE Trans. Dielectr Electr Insul 
(2009);16(5):1243-50.

DOI: 10.1109/TDEI.2009.5293934

28. Delemotte L, Tarek M. Molecular dynamics simulations of lipid membrane electroporation. J Membr Biol (2012);245:531-43. DOI: 10.1007/s00232012-9434-6

29. Neumann E, Rosenheck K. Permeability changes induced by electric impulses in vesicular membranes. J Membr Biol. (1972);10:279-90. DOI: 10.1007/BF01867861

30. Teissié J, Golzio M, Rols MP. Mechanisms of cell membrane electropermeabilization: a minireview of our present (lack of?) knowledge. Biochim Biophys Acta (2005);1724:270-80. DOI: 10.1016/j.bbagen.2005.05.006

31. Escoffre JM, Portet T, Wasungu L, Teissié J, Dean D, Rols MP. What is (still not) known of the mechanism by which electroporation mediates gene transfer and expression in cells and tissues. Mol Biotechnol (2009);41:28695. DOI: 10.1007/s12033-008-9121-0

32. Tang LL, Sun C, Liu H, Mi Y, Yao CG, Li CX. Steep pulsed electric fields modulate cell apoptosis through the change of intracellular calcium concentration. Colloids Surf. B Biointerfaces (2007);57:209-14. DOI: 10.1016/j.colsurfb.2007.02.008

33. Joshi RP, Schoenbach KH. Bioelectric effects of intense ultrashort pulses. Crit Rev Biomed Eng. (2010);38:255-304. DOI: 10.1615/CritRevBiomedEng.v38.i3.20

34. Davalos R, Mir L, Rubinsky B. Tissue ablation with irreversible electroporation. Ann Biomed Eng. (2005);33:223-31. DOI: 10.1007/s10439-005-8981-8

35. Breton M, Mir LM. Microsecond and nanosecond electric pulses in cancer treatments. Bioelectromagnetics. (2011) Aug 3. doi: 10.1002/bem.20692. DOI: 10.1002/bem.20692

36. Nuccitelli $R$, Chen $X$, Pakhomov AG, Baldwin WH, Sheikh S, Pomicter JL, Ren W, Osgood C, Swanson RJ, Kolb JF, Beebe SJ, Schoenbach KH. A new pulsed electric field therapy for melanoma disrupts the tumor's blood supply and causes complete remission without recurrence. Int $\mathbf{J}$ Cancer. (2009);125:438-45. DOI: 10.1002/ijc.24345

37. Beebe SJ, Chen X, Liu JA, Schoenbach KH. Nanosecond pulsed electric field ablation of hepatocellular carcinoma. Conf Proc IEEE Eng Med Biol Soc. (2011);2011:6861-5. DOI: 10.1109/iembs.2011.6091692

38. Frey W, White JA, Price RO, Blackmore PF, Joshi RP, Nuccitelli R, Beebe SJ, Schoenbach $\mathrm{KH}$, Kolb JF. Plasma membrane voltage changes during nanosecond pulsed electric field exposure. J Biophys (2006);90:3608-15. DOI: 10.1529/biophysj.105.072777

39. Chen W, Lee RC. Evidence for electrical shock-induced conformational damage of voltage-gated ionic channels. Ann NY Acad Sci (1994);720:124-35. DOI: 10.1111/j.17496632.1994.tb30440.x

40. Chen W. Electroconformational denaturation of membrane proteins. Ann NY Acad Sci. (2005);1066:92-105.

DOI:

10.1196/annals. 1363.028

41. Chen W, Zhongsheng Z, Lee RC. Supramembrane potential induced electroconformational changes in sodium channel proteins: A potential mechanism involved in electric injury. Burns (2006);32:52-9.

10.1016/j.burns.2005.08.008

42. Nesin V, Bowman AM, Xiao S, Pakhomov AG. Cell permeabilization and inhibition of voltage-gated $\mathrm{Ca} 2+$ and $\mathrm{Na}+$ channel currents by nanosecond pulsed electric field. Bioelectromagnetics. (2012);33:394-404. DOI: 10.1002/bem.21696

43. Vernier PT, Sun Y, Marcu L, Craft CM, Gundersen MA. Nanoelectropulse-induced phosphatidylserine tranlocation. J Biophys (2004)86:4040-80.

DOI: 10.1529/biophysj.103.037945

44. Budhu A, Jia HL, ForguesM, Liu CG, GoldsteinD, et al. Identification of metastasis related microRNAs in hepatocellular carcinoma. Hepatol (2008);47: 897-907. DOI: 10.1002/hep. 22160

45. Zhou L, Liu J, Luo F. Serum tumor markers for detection of hepatocellular carcinoma. World J Gastroenterol (2006);12:1175-81.

46. Li MS, Ma QL, Chen Q, Liu XH, Li PF, Du $\mathrm{GG}$, et al. Alpha-fetoprotein triggers 
hepatoma cells escaping from immune surveillance through altering the expression of Fas/FasL and tumor necrosis factor related apoptosis-inducing ligand and its receptor of lymphocytes and liver cancer cells. World J Gastroenterol (2005);11:2564-9. DOI: 10.3748/wjg.v11.i17.2564

47. Cavin LG, Venkatraman M, Factor VM, Kaur S, Schroeder I, Mercurio F, et al. Regulation of alpha-fetoprotein by nuclear factor-kappaB protects hepatocytes from tumor necrosis factor-alpha cytotoxicity during fetal liver development and hepatic oncogenesis. Cancer Res (2004);64: 7030-8. DOI: 10.1158/00085472.CAN-04-1647

48. Belayew A, Tilghman SM. Genetic analysis of alpha-fetoprotein synthesis in mice. Mol Cell Biol (1982);2:1427-35.

49. Tilghman SM, Belayew A. Transcriptional control of the murine albumin/alpha- fetoprotein locus during development. Proc Natl Acad Sci USA (1982);79:5254-7. DOI: 10.1073/pnas.79.17.5254

50. Dong ZZ, Yao DF, Yao M, Qiu LW, Zong L, $\mathrm{Wu} \mathrm{W}$, et al. Clinical impact of plasma TGFbeta1 and circulating TGF-betal mRNA in diagnosis of hepatocellular carcinoma. Hepatobiliary Pancreat Dis Int( 2008); 7:28895.

51. Derynck R, Goeddel DV, Ullrich A, Gutterman JU, Williams RD, Bringman TS, et al. Synthesis of messenger RNAs for transforming growth factors alpha and beta and the epidermal growth factor receptor by human tumors. Cancer Res (1987);47:707-12. 